\title{
Covid-19 and Social Distancing of the Elderly: The Importance of Physical Exercise
}

\section{Samuel Gonçalves Almeida da Encarnação a , Osvaldo Costa Moreira ${ }^{b}$, Sthéfany Lemos Fazolo a, Cláudia Eliza Patrocínio de Oliveira a, Irismar Gonçalves Almeida da Encarnação c, Miguel Araujo Carneiro-Júnior a,*}

a Department of Physical Education, Universidade Federal de Viçosa, Viçosa-MG, 36570-900, Brazil

b Institute of Biological Science and Health, Universidade Federal de Viçosa - Campus Florestal, Florestal-MG, 35690-000, Brazil c School of Education, Instituto Politécnico de Bragança - Campus Santa Apolónia, Bragança, 5300-253, Portugal

*Corresponding Author Email: miquel.junior@ufv.br

DOI: https://doi.org/10.34256/ijpefs21211 s

Received:08-03-2021 Revised:22-06-2021; Accepted: 24-06-2021; Published: 25-06-2021

Abstract: The infectious disease COVID-19 (Coronavirus Disease 2019) caused by the severe acute respiratory syndrome coronavirus 2 (SARS-CoV-2), appeared at the end of 2019 in China, and spread rapidly throughout the world in the first months of 2020. The elderly or anyone with chronic illnesses such as obesity, high blood pressure, lung disease and diabetes, are considered part of the risk group. Health authorities around the world began to adopt and encouraged behaviors to mitigate the risk of transmission, such as washing hands frequently with soap and water, making social distancing, and staying at home if possible, in order to minimize the infection and thereby relieve the health systems and reduce the number of fatalities. In this review, we discuss the possible effects of social distancing on the health of the elderly and describe different strategies of physical exercise to be performed during the pandemic of COVID-19. Aerobic training, strength training and high-intensity interval training (HIIT) are effective for improving immune functions, autonomy, functional independence, and mental health in the elderly during the COVID-19 pandemic. In addition, physical exercise programs must be planned, adapted, and controlled based on the individual capabilities of the elderly, and remotely guided by professionals trained in the prescription of physical exercise. It is necessary that the general population, and especially the elderly, be continuously informed, protected, and oriented about the benefits and the importance of physical exercise practice during the social distancing caused by the pandemic of COVID-19.

Keywords: COVID-19, Aging, Exercise, Health, Quality of life, Physical distancing.
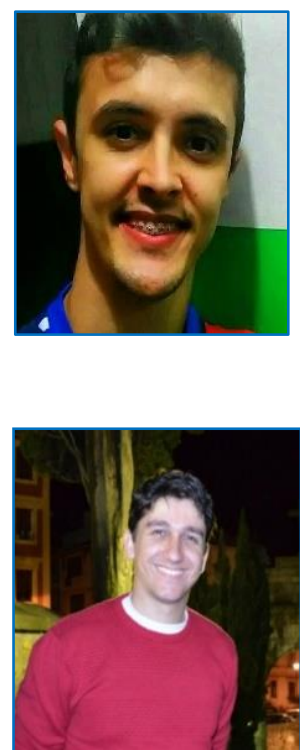

Mr. Samuel Gonçalves Almeida da Encarnação is a Master's student in Physical Education at the Universidade Federal de Viçosa (UFV) and is a member of the Study and Research Group on Physical Activity and Aging (GEPAFE), led by Dr. Miguel Araujo Carneiro Júnior, $\mathrm{PhD}$.

Dr. Osvaldo Costa Moreira has $\mathrm{PhD}$ in Physical Activity Sciences and Sports at the University of Leon - Spain. Currently he is professor at Institute of Biological Sciences and Health at the Universidade Federal de Viçosa - Brazil.

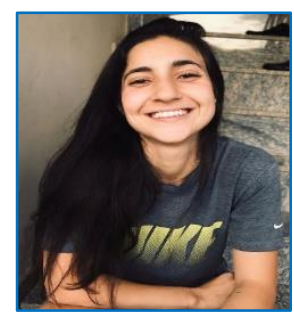

Júnior, PhD.

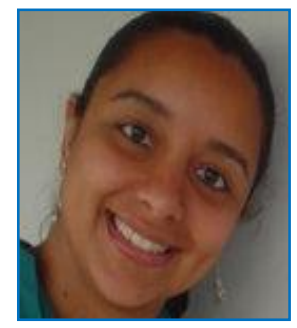

Ms. Sthéfany Lemos Fazolo is a graduate student in Physical Education at the Universidade Federal de Viçosa (UFV) and is a member of the Study and Research Group on Physical Activity and Aging (GEPAFE), led by Dr. Miguel Araujo Carneiro

Dr. Claudia Eliza Patrocínio de Oliveira has $\mathrm{PhD}$ in Physical Activity Sciences and Sports at the University of Leon - Spain. Currently she is professor at Department of Physical Education at the Universidade Federal de Viçosa - Brazil. 


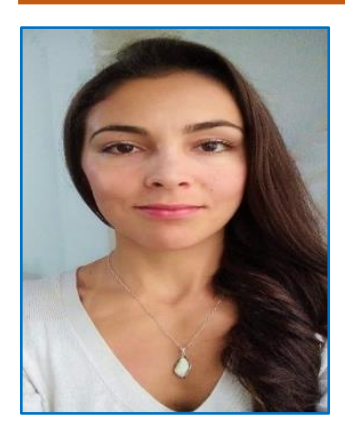

Ms. Irismar Gonçalves Almeida da Encarnação is a Master's student in Exercise and Health at the Instituto Politécnico de Bragança (IPB), Bragança, Portugal and is a member of the Kinanthropometry and Human Performance Laboratory (LCDH) of Instituto Federal de Educação Ciência e Tecnologia do Sudeste de Minas Gerais, Rio Pomba, Minas Gerais, Brazil, led by Dr. João Batista Ferreira-Júnior, PhD.



Dr. Miguel Araujo
Carneiro-Júnior has a
Master's Degree in Physical
Education at the
Universidade Federal de
Viçosa (UFV) and a PhD in
Physiological Sciences at the
Universidade Federal do
Espírito Santo (UFES).

Professor in the Department of Physical Education and coordinator of the Stricto-Sensu PostGraduate Program in Physical Education at UFV. Leader of the Study and Research Group on Physical Activity and Aging (GEPAFE).

\section{Introduction}

The world is been affected by the pandemic he pandemic of the infectious disease COVID-19 (Coronavirus Disease 2019) caused by the severe acute respiratory syndrome coronavirus 2 (SARS-CoV2), which appeared at the end of 2019, in Wuhan city, in China, and spread rapidly throughout the world in the first months of 2020 [1] Due to its high adaptability to different climatic conditions the infection is rapidly reaching about 115 countries around the world [2], and until June 22th, there were 175 million confirmed cases and 3.87 million deaths, reported to World health organization (WHO) [3]. In addition, the disease is characterized by a high rate of contagion, in which each individual who contracts COVID-19 transmits it to two more people, on average [1].

Primarily the virus is transmitted by air currents from sneezing, breathing, and talking, then it infects the cells that line the air passages. From this occurs the infection by SARS-CoV-2, through the spike protein, present in the extremities of the virus, which is activated by the Transmembrane protease serine 2 (TMPRSS2), and binds to human angiotensin- converting enzyme 2 (ACE-2) receptors. The infection usually causes mild symptoms of cold, fever, shortness of breath, body pain and diarrhea before being neutralized by immune cells [4].

However, when COVID-19 reaches the lungs, where there is a high concentration of ECA-2, it ends up generating downregulation of this enzyme, causing an imbalance of the renin-angiotensin-aldosterone system, leading to vasoconstriction of the alveoli, changes in vascular permeability, myocardial remodeling and lung injury [5]. Due to the vasoconstriction of the alveoli, there is an accumulation of local inflammation, known as "immune system inflammatory cytokine storm" [6], which causes the hyperinflammation of the lungs, leading to acute respiratory syndrome, marked by increases in inflammatory cytokines such as interleukin 6 (IL-6), monocyte-chemoprotein protein 1 (MCP-1) and granulocyte colony stimulating factor (GCSF), which are also inflammatory markers released after strenuous exercise $[2,7]$.

The risk group includes the elderly or anyone with chronic illnesses such as obesity, high blood pressure, lung disease, diabetes, some condition that causes immunosuppression, among others [8]. In the case of the elderly, there is an increased risk of fatality, $\leq 70$ years old $(13 \%)$ and $\leq 80$ years old ( 15 to $20 \%$ ) [9]. Without a definitive cure for COVID-19, health authorities around the world began to adopt and encouraged behaviors to mitigate the risk of transmission, such as washing hands frequently with soap and water, making social distancing (set of actions that seek to limit social interaction in order to stop or control the spread of contagious diseases), and staying at home as long as possible, in order to minimize contagion and thereby relieve the health systems and reduce the number of fatalities $[7,8]$.

Another major concern has been the possible impacts of the COVID-19 pandemic on the mental health of the elderly [10]. Data from the 2003 severe acute respiratory syndrome (SARS) epidemic reported a $30 \%$ increase in the suicide incidence rate in people aged 65 and over, and about $50 \%$ of the infected elderly who recovered remained anxious $[11,12]$. Studies have explained that the necessary and inevitable social distancing during the pandemic increases the feeling of loneliness and contributes to the increase of stress, anxiety, depression and suicidal ideas during the continuation of the elderly's life [1315]. 
In addition, these afflictions can be aggravated in groups of socioeconomically disadvantaged elderly people, with a higher level of poverty, where financial insecurity predisposes them to higher rates of mental damage than financially stable counterparts $[16,17]$. Authors reveal the need for public policies that provide ways to occupy the elderly, reducing the idle time, maintaining health, well-being and quality of life, which are considered important measures to be taken during the period of social distancing [18-20].

In addition to mitigation strategies, the adoption of a physically active lifestyle has been guided in the scientific literature as a possible protective factor of the immune system, effective in improving the physical functions of elderly individuals [21-23]. Therefore, the objective of this review is to discuss the possible effects of the social distancing caused by the pandemic of COVID-19 on the health of the elderly and describe different strategies of physical exercise to be carried out during the social distancing caused by the pandemic of COVID-19 in order to assist in maintaining the health of these people.

Social distancing, physical inactivity, and health implications for the elderly

The promotion of active aging, together with strategies that provide support for improving the autonomy and independence of the elderly, are essential to avoid early mortality, functional limitations, and thereby improve the quality of life and well-being of these people $[24,25]$. However, social distancing is the main way of mitigating the transmission indexes of COVID-19 [26]. As a consequence, many individuals reduce the level of physical activity (PA), and in the specific case of the elderly it is more accentuated, and can bring problems such as the evolution of sarcopenia, frailty, chronic diseases, increases in the rate of obesity [27], in addition to worsening the mental health and quality of life of these people [1].

Obesity, defined as an increase in body mass index (BMI), hip circumference, and the percentage of fat in the central and peripheral regions of the body [28], is associated with higher mortality rates during old age [29]. According to longitudinal data, from 2015 to 2020 , the number of elderly people grew from 900 million to 2 billion [30]. In addition, data show that by 2030, there will be an absolute number of 2.16 billion (38\%) overweight adults worldwide, and 1.2 billion $(20 \%)$ obese adults, showing tha0t if correct intervention measures are not taken, we will soon have an "elderly and obese" planet $[31,32]$.
Obesity is an important risk factor for COVID19 and its complications [33], being strongly associated with physical inactivity, it is considered the central factor for the appearance of the metabolic syndrome, which is related to other chronic diseases such as high blood pressure, diabetes and cardiovascular disease, which are also risk factors for those infected with COVID-19 [7,8]. When obese people are infected by viral agents, they have exacerbated levels of systemic inflammation, called the "inflammatory cytokine storm", and its outcome is the reduction of the body's autoimmune capacity $[34,35]$. In the case of the elderly, a natural phenomenon known as immunosenescence occurs, in which defense cells, such as NK (natural killers) and T lymphocytes have their function suppressed, in addition to the fact that naturally the elderly have higher pro-inflammatory processes, and in a chronic way, a process known as "inflammaging", making them more vulnerable to the entry of viral agents and less resistant to fight these invaders inside the organism [36]. In addition, obese elderly people have even greater levels of inflammation and unregulated cardiometabolic markers, which attributes to them multiplied risks for infection caused by COVID-19 disease [22,37].

Recent estimates collected from 30 million active users of the Fitbit bracelet show comparisons between the months of March 2019 and 2020, in which in the U.S. there was a $12 \%$ daily reduction in the number of steps, and in Spain, Italy and Brazil there were even greater reductions of 38, 25 and 15\%, respectively [38]. A recent qualitative study showed that the lack of guidance causes the elderly to reduce their motivation to adhere to regular physical exercise, increasing the level of physical inactivity [39]. It is known that about $\leq 1500$ steps per day is considered a low value of $P A$, while around $\geq 10,000$ steps per day is considered a high level of daily physical activity [40]. Another important data shows that the average reduction of 1000 to 1500 steps per day is associated with increased muscle resistance to glucose entry, which contributed to a catabolic and inflammatory condition, besides reducing muscle mass by about $4 \%$ in just 14 days [41].

Sarcopenia had its concept recently updated by the European Working Group on Sarcopenia in Older People (EWGSOP), as a progressive and generalized muscle disorder that is associated with an increased likelihood of adverse outcomes including falls, fractures, physical disability and mortality [25]. Sarcopenia is diagnosed when an subject have low 
muscle strength, along with low muscle quantity $\left(\mathrm{kg} / \mathrm{m}^{2}\right)$ and/or muscle quality (determined in the research by the accumulation of intramuscular fat), and when a reduced functional performance is added, sarcopenia is considered to be in a severe state [4244].

In addition, it is known that the magnitude of the negative outcomes of sarcopenia is even greater when the subjects remain in physical inactivity for prolonged periods of time [45-47]. Several studies have shown that the decrease or interruption of participation in physical exercise activities and programs can lead to loss of acquired adaptations (i.e., detraining) $[48,49]$. Studies have been revealing that in the case of elderly people, losses in muscle power and functionality to perform activities of daily living (ADLs) occur at an accelerated rate, which is considered a risk factor for frailty and early mortality $[50,51]$. In addition, worsening in cardiometabolic parameters and increases in the incidence of obese phenotypes are strongly associated with the cessation of training and with the increase in physical inactivity in the elderly [22,52-54].

Another point that must be considered is the mental health of the elderly, which is also directly affected during social distancing [10]. The WHO defines mental health as "a state of well-being in which the individual realizes his or her own abilities, can cope with the normal stresses of life, can work productively and fruitfully, and is able to make a contribution to his or her community" [55]. (WHO, 2014). In contrast, mental disorders are conceptualized as "a combination of abnormal thoughts, perceptions, emotions, behaviors and relationships with others". Depression, bipolar disorder, schizophrenia, dementia, autism and other psychoses are considered mental disorders [56]. Analysis data in 28 countries around the world show that mental disorders affect about $36 \%$ of people [57]. In addition, data has been showing that people with low levels of physical activity have shown greater psychological stress than those who are more active, and elderly people aged $\geq 70$ years form the group with lower levels of PA, reinforcing the need for personalized monitoring for these people [58].

Physical exercise is conceptualized as "a subcategory of physical activity that is planned, structured, repetitive, and purposefully focused on improvement or maintenance of one or more components of physical fitness" [59]. Physical exercise is considered an effective way to control obesity, preserve functional autonomy and reduce the manifestation of chronic diseases, as well as maintain the balance of the immune system in elderly people $[23,60]$. In addition, a physically active lifestyle, through any type of exercise that causes increased energy expenditure [61], is associated with improved sleep $[62,63]$, and improved cognition throughout life $[64,65]$, being an important component for mental health and healthy aging [66]. Therefore, in the next topics will be addressed some indications of types of physical exercises to control obesity, improvement of the immune system, maintenance of autonomy and functional independence and mental health of the elderly during the social distancing from the pandemic of COVID-19.

\section{Materials and Methods}

It is a brief narrative review, done through a search in the databases PubMed (Medline) and Cochrane Library. For this search was used a basic combination of the next boolean operators and their respective entry terms: Population: elderly; Intervention: aerobic training, strength training, highintensity interval training (HIIT) and Outcome: physical health, mental health, muscle strength, physical fitness, physical functional performance in which was selected the articles that treated effects of physical exercise in health parameters of elderly people, as neuromuscular, cardiovascular, functional performance, immune system, cognitive and mental health benefits.

\section{Discussion}

\subsection{Physical exercise for the elderly during the pandemic \\ Aerobic training}

Aerobic exercise is defined by the maintenance of efforts for long periods, where the energy for the maintenance of the effort comes mainly from the aerobic metabolism, which promotes the complete combustion of carbohydrates and fats and, in some cases, of proteins in the presence of oxygen [67]. It is known that, in general, aerobic exercise promotes benefits to immune function and improves the ability to perform activities of daily living (ADLS). However, when performed for long periods (> $60 \mathrm{~min}$ ), and intensely $\left(>75 \% V \mathrm{VO}_{2 \max }\right)$, it can cause the suppression of immune functions, a process known as the "window of opportunity", in which the organism is more susceptible to various viruses and infections [68-70]. There are several studies in the literature that have shown positive acute responses on the immune 
function of the elderly, such as increased activity of NK cells and natural cellular-mediated tumor cytotoxicity (NCMTC) [71-74].

In a controlled and randomized study with women aged 65-85 years, Nieman et al. [70] verified the association of the level of aerobic conditioning, the concentration of NK cells and the incidence of upper respiratory tract infections (URTI). At first, highly active women in aerobic exercise exhibited greater activity of NK cells and function of T cells compared to inactive women. After this first comparison, part of the group of inactive women was randomized to the control or training group [30-40 min walk at $60 \%$ heart rate reserve (HRR), 5 days a week, for 12 weeks]. After training, there was an increase in maximum oxygen consumption $\left(\mathrm{VO}_{2} \mathrm{max}\right)$, but without improvements in the immune system. In addition, the group of highly active elderly women had a lower incidence of URTIs compared to the group of sedentary women who trained or in relation to the control group.

In another controlled, randomized trial, the effects of 6 months of aerobic training on immunity markers of elderly, physically inactive men and women aged 64-67 years were compared. The aerobic training protocol consisted of 40 minutes of walking three times a week, at an intensity of $52 \%$ of the HRR. At the end of the study, the subjects showed significant increases in $\mathrm{VO}_{2 \max }$ ), in the proliferation of $\mathrm{T}$ lymphocytes and cells, indicating improvements in aerobic fitness along with improved NK antiviral defense [75]. In a controlled trial, Yan et al. [76] compared three age groups composed of men who regularly practiced aerobic activities in the last three years (young people, 20-39 years old; middle age, 40-59 years old; and elderly people, $\geq 60$ years old), with their respective physically inactive controls. After training, it was noted that the elderly group showed a small increase in the concentration of CD4+ CD3+ T lymphocyte, and a more pronounced increase in the number of NK cells when compared to their inactive controls. It is known that with the aging process there is a decrease in T-cell function and innate immunity, which can increase the risk of contracting diseases, infections, malignant tumors, and autoimmune diseases [77]. Thus, the results of this study are extremely important for the health of the elderly, since the intervention with moderate aerobic exercise was able to decrease some factors that increase such risks.

In another study, the effect of moderate aerobic exercise on the concentration of antibodies in the elderly (> 64 years) was found. The elderly were randomized to the control group (CG, $n=13$ ) or experimental group ( $E G, n=14)$. $E G$ participated in 10 months of low-intensity aerobic training $(65-75 \%$ of HRR), performed on treadmill exercises, ascending steps, remoergometers and cycloergometers, performed 3 times a week and lasting 25-30 minutes, and the CG was recommended to continue their normal activities of life, but without undergoing any systematic intervention. Both groups were previously vaccinated against influenza before the start of the intervention. After the intervention, it was noted that the subjects of the EG had a greater stimulation for the antibodies of the influenza vaccine when compared to the $C G$, that received only the treatment with the vaccine [78]. The mechanisms related to the modulation of the immune system by physical exercise have not yet been elucidated, however some acute and chronic responses may be related to this modulation [79]. According to Kapasi et al. [80], the changes triggered by physical exercise in the response to immunization to influenza are mediated by neuroendocrine interaction (greater activation of the sympathetic nervous system and hypothalamic-pituitary axis) and the immune system, probably by endogenous opioids, but further studies on this topic are needed.

In addition to the benefits on the immune system of the elderly, aerobic exercise also improves cognitive function and prevents the decrease in the volume of the subfields of the hippocampus [36], improves functional capacity, sleep quality and acts as a blood pressure regulator $[81,82]$. It is important to remember that aerobic training, when plunged in intensities and progressive volumes, and monitored constantly, has a very low risk to the health of different groups, such as elderly people with acute myocardial infarction [83], middle-aged adults and the elderly with type 2 diabetes [84], and hypertensive elderly [85]. In this sense, it is suggested to practice aerobic training at least three times a week, spending an average of at least 30 minutes, not overcoming 60 minutes for the overall health security of the elderly. It is important to highlight during this practice the care with guidance, supervision, hygiene, and social distancing during the COVID pandemic [86].

\section{Strength training}

Strength training is characterized by dynamic or static muscle action as opposed to external resistance, typically performed with free weights or machines and provides several benefits to its 
practitioners [67]. Strength training can contribute to regulating the lipid profile, reducing obesity and increasing muscle mass, which are factors that reduce inflammation and strengthen the immune system [87]. Recent studies with strength training have found improvements in immune functions and decreased inflammation in elderly people [88-91]. In a systematic review it was shown that strength training with moderate intensity $(50-60 \% 1 \mathrm{RM})$ to high intensity (70-80\% 1RM), performed on machines or with free weights, is capable of generating positive effects of moderate to large magnitudes on the inflammatory profile [increased IL-1, decreased IL- 6 and decreased Tumor Necrosis factor-alpha (TNF-a)] and functional autonomy (e.g. sit and stand test 5 times) of the elderly [92].

Tomeleri et al. [93], from the evaluation of venous blood samples, noticed a significant reduction in the expression of IL-6, TNF- $a$ and C- reactive protein (CRP) in women aged $48-68$ years after 8 weeks of strength training, 3 times a week, 3 sets of 10-15 repetitions of 8 exercises for the whole body, with exercises performed with free weights (biceps curls) and with machines (bench press, horizontal leg press, rowed in a sitting position, knee extension, knee flexion, elbow extension in the high pulley, and plantar flexion in a sitting position). In addition, Chupel et al. [94], collected blood samples in the morning, 2 weeks before and after 28 weeks of strength training with elastic bands, in order to verify the inflammatory profile and cognition of elderly women aged 80-90 years. After the intervention, increases in IL-10, and hemoglobin, and reduction in leukocytes and $T$ lymphocytes were noted, with no changes in TNF-a. IL-10 is considered a key cytokine in the antiinflammatory process, in addition to being responsible for inhibiting the exacerbated increase in TNF-a, which is a marker of inflammation responsible for causing neuronal damage and cognitive dysfunction in the elderly [95], while leukocytes and lymphocytes at high levels are associated with inflammation and worsening cognition [96]. The increased hemoglobin corresponded to improvements in oxygen transport, suggesting an increase in the level of aerobic fitness [97]. The experimental group achieved improvements in cognition, accompanied by reductions in inflammation, a fact that confirms the cognitive benefits of exercise [98]. However, in the control group there was an exacerbation of inflammation, identified by an increase in CRP and TNF-a.
Other recent studies have shown the positive effects of strength training on reducing inflammation in elderly women with breast cancer [99], in elderly women with cognitive impairment [94], and in healthy postmenopausal women [100]. In addition, Mcfarlin et al. [101] identified a low expression of TRL4 (Toll like receptor-4) in elderly women practicing strength training, aged $65-80$ years. TRL4 is responsible for recognizing foreign molecules, thus, the reduction of its expression indicates improvements in innate immunity [102]. There is also positive evidence of the effects of combined training (strength + aerobic) on adaptations of the immune system in the elderly, such as the reduction of TNF-a, IL- 6 , and the percentage of $\mathrm{CD}_{14}{ }^{+}$and $\mathrm{CD} 16^{+}$monocytes [103]. In addition, the performance of combined training is interesting because it manages to promote different adaptations from both strength training and aerobic training for the elderly, how to improve neuromuscular function and fitness for ADLs, as well as respiratory and cardiovascular adaptations, all of which are inversely associated with early mortality $[104,105]$.

There are also studies that have not shown improvements in immune system markers after strength training with moderate intensity, but there is also no evidence that it causes worsening immunity $[102,106]$. On the other hand, caution should be taken when performing protocols that have high intensity and/or high volume at the beginning of the strength training program, because the subjects are not yet adapted. High intensity strength training can damage sarcomeres and suppress NK cells. This shows the need to adopt low to moderate loads and/or volumes, as well as progressive increases throughout the strength training program $[23,107]$.

In addition, strength training should be considered as a fundamental component of physical exercise programs for the elderly during social distancing, as it improves autonomy and functional independence for performing ADLs $[108,109]$. For elderly with a more advanced training level, protocols that have speed components during concentric contractions are also suggested, featuring muscle power movements [110]. Within this perspective, another type of alternative physical exercise for the isolation period is the performance of training based on the use of one's own body weight, which can also bring improvements in the autonomy, functional independence and quality of life of the elderly, without the need for specific materials and equipment [111]. 
Based on the exposed evidence, we suggest that the elderly can practice strength training an average of three times a week, with a volume of 3 sets of 10-15 repetitions, an amount of 8 whole-body exercises, and whenever possible embodying maximal velocity of movement in the exercises (power training). It is important to remember that the coaches must ensure that this suggestion of volumes and intensities, as well as the progression and complexity of training, are adapted according to the individuality of each subject, considering important aspects of health i.e., existence or not of chronic diseases, comorbidities, cognition status and previous experience with strength training [108]. Thus, it is a method that contributes to the maintenance and improvement of the physical, mental health, and quality of life of elderly people during the period of social distancing caused by the pandemic of COVID-19. It is also important to highlight during this practice the preventive measures against COVID-19 infection [112].

\section{High-intensity interval training (HIIT)}

High-intensity interval training (HIIT) is conceptualized as "brief intervals of vigorous activity, interspersed with periods of low activity or rest", which can produce a strong physiological response in an acute manner. The objective of the HIIT method is to accumulate high intensity activities, around $90 \%$ of the peak oxygen utilization $\left(\mathrm{VO}_{2 \text { peak }}\right)$, or $90 \%$ of the maximum heart rate $\left(\mathrm{HR}_{\max }\right)$, so that the individual is unable to continue the exercise for long periods. In addition, rest time must be planned to return to exercise within the intensity programmed for the training session [113]. Studies with HIIT found in the literature are characterized by protocols that use cycle ergometers, running and walking on a treadmill, emphasizing body movements that require several joints [114-116].

HIIT has its safety and viability proven both in healthy populations [57], and for populations with risk conditions, such as cardiac patients [117], patients with chronic kidney disease [118], adults and elderly with type 2 diabetes [119] and frail and pre-frail elderly [120], being effective in controlling metabolism, blood pressure and improving immune function $[115,121,122]$. It is also associated with improved autonomy and independence to perform activities of daily living, and is inversely associated with the risk of death from cardiovascular disease in the elderly [123125].
In a recent study, Durrer et al. [126] tested the acute effects of a single HIIT session, consisting of 7 sprints of 1 minute, with intensity of $85 \%$ of $\mathrm{VO}_{2 \max }$ in inflammation markers in 10 subjects ( 5 men and 5 women), diagnosed with type 2 diabetes, aged 47-68 years and in 9 non-diabetic controls (4 men and 5 women) of the same age. One hour after the session, individuals in both groups showed reductions in TNF-a levels, and low expressions of the Toll like receptor-2 protein (TRL2) on the surface of the monocytes accessed in the blood. Within what is known, TRL2 and monocytes $\mathrm{CD}_{14}{ }^{+}$and $\mathrm{CD} 16+$ are associated with proinflammatory mechanisms and increased cardiovascular risk factors such as insulin resistance and atherosclerosis $[127,128]$. Thus, reductions in chronic inflammation were noted, which are considered to be protective factors of the innate immune system and to reduce insulin resistance and cardiovascular risk [128-130]. These studies proved the effectiveness of HIIT in improving the inflammatory profile even in healthy individuals, revealing preventive effects against type 2 diabetes.

In another study, Bartlett et al. [131] verified the effects of 10 weeks of an HIIT protocol with walking, 3 days a week, 30 minutes per session, consisting of intervals of exercise $80-90 \%$ of reserve oxygen consumption ( $\mathrm{VO}_{2 \text { reserve) }}$ and active recovery (80-90\% VO2reserve), both lasting 60 seconds, in inflammation and immunity markers of 12 sedentary subjects (11 women and one man), diagnosed with rheumatoid arthritis (RA), aged 57-64 years. After the intervention, reductions in resting $H R$ and mean arterial pressure (mean BP) were noted, which represent an important protective factor against cardiovascular diseases and premature mortality [132,133]. In addition, increases in the concentrations of reactive oxygen species and bactericidal phagocytes have been observed, revealing an improvement in neutrophil function to attack and destroy invading bactericidal agents [134]. Another important adaptation was the reduction in the frequencies of CD14+/CD16+ monocytes that are directly associated with increased inflammation in RA patients, accompanied by increases in the frequency of $\mathrm{CD} 14^{\text {bright }} / \mathrm{CD} 16^{\text {negative }}$ monocytes, which are inversely correlated with inflammation from RA [135].

In another study, Steckling et al. [136] tested the effects of 12 weeks of HIIT on a treadmill, performed 3 times a week, on the inflammatory and adipokine profile of 15 post-menopausal women aged 53-59 years. The training consisted of four sprints at 
$90 \% \mathrm{VO}_{2 \max }$, interspersed with an active three-minute rest at $70 \% \mathrm{VO}_{2 \max }$.
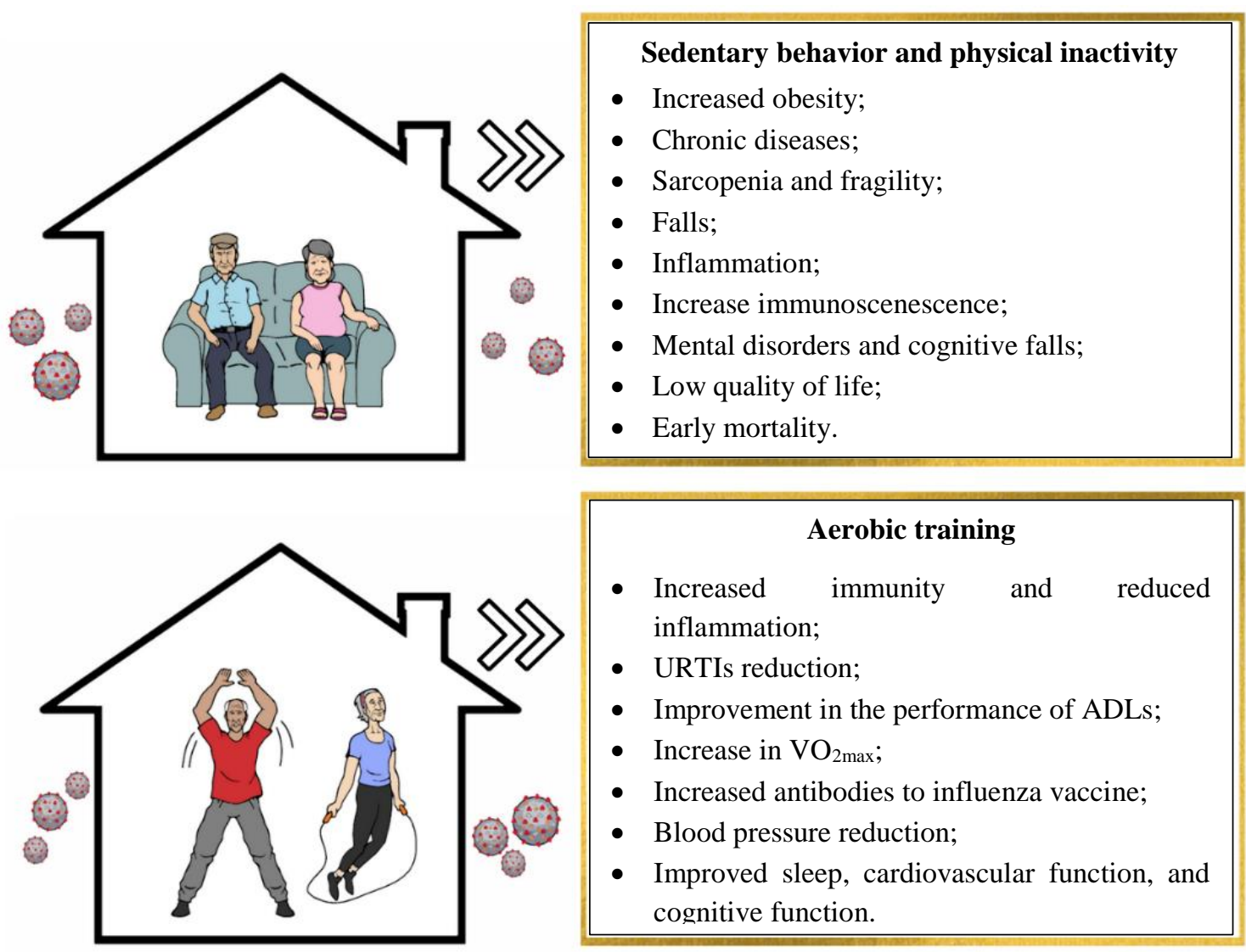

\section{Aerobic training}

- Increased immunity and reduced inflammation;

- URTIs reduction;

- Improvement in the performance of ADLs;

- Increase in $\mathrm{VO}_{2 \max }$;

- Increased antibodies to influenza vaccine;

- Blood pressure reduction;

- Improved sleep, cardiovascular function, and cognitive function.
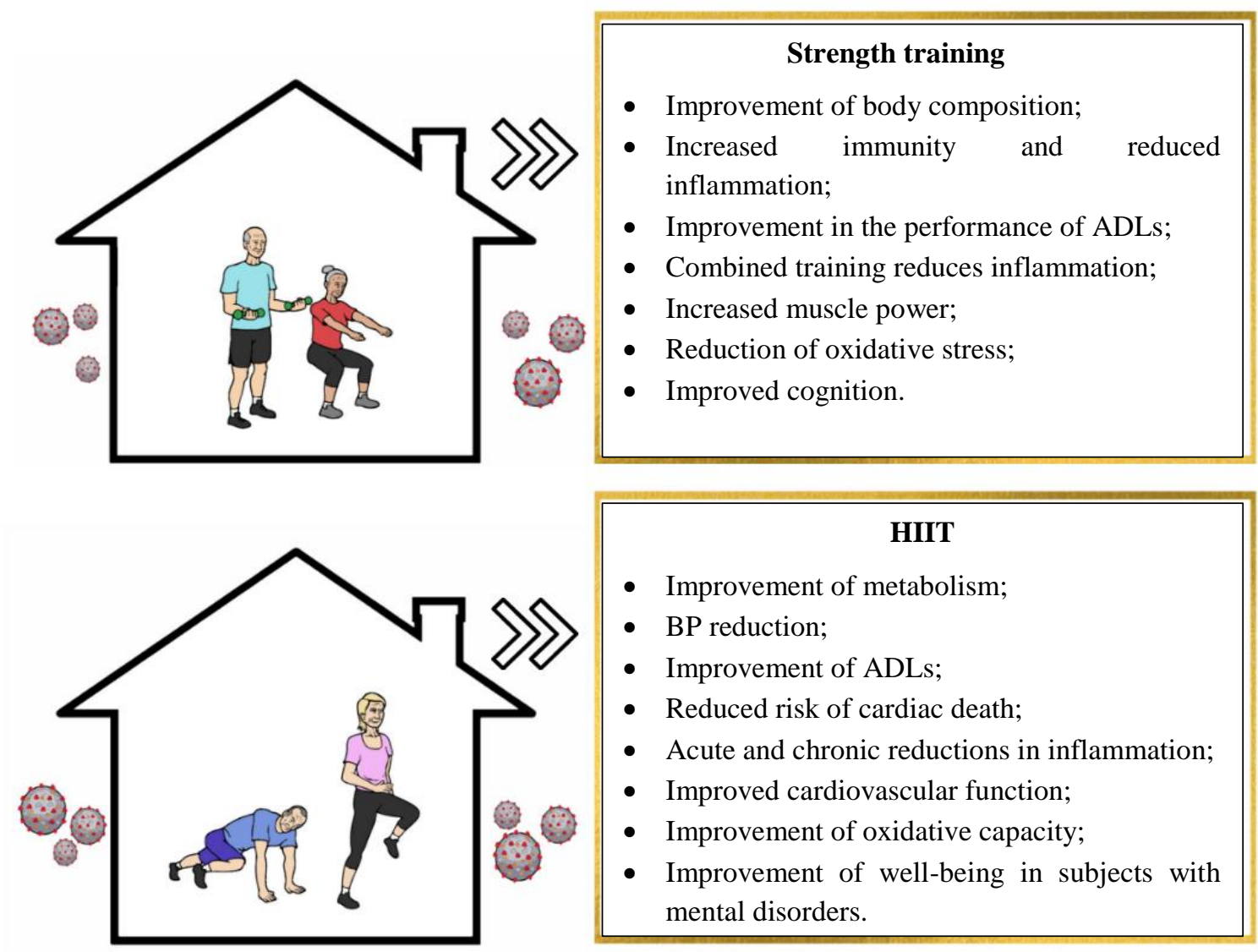

Figure 1 Effects of sedentary behavior and physical inactivity, aerobic training, strength training, and HIIT (highintensity interval training) on the physical and mental health of the elderly during social distancing caused by COVID-19. 
After the intervention, there was a reduction in the expression of TNF-a, IL-6, IL-10, p65 and $\beta$-actin, and of adipokines: resistin, leptin, ghrelin, that are associated with increased concentration of abdominal fat and have been described as mediators of increased insulin resistance [137]. In addition, increases in adiponectin concentrations were found, which is known to have important anti-atherogenic and antiinflammatory functions, to have cardioprotective factors and to be inversely associated with obesity $[138,139]$.

In addition, Heggelund et al. [140] verified the effects of a single HIIT session, with an intensity of $85-90 \% \mathrm{FC}_{\max }$, on the feeling of well-being of men and women aged 26-52 years, who were separated into two groups, the first group was the control group, formed by subjects with no diagnosed mental disorder (CG) and the second group was made up of subjects with a confirmed diagnosis of depression and schizophrenia (EG). Collections of a sense of well-being were performed $15 \mathrm{~min}$ and 3 hours after the HIIT session. At the end of the study, it was noted that the positive effect on well-being occurred in both groups, but a prolonged effect ( 3 hours later), only occurred in the EG.

The depression level did not change in any of the groups, but evidence shows that sustained improvements in well-being are inversely correlated with depression, and if sustained over long periods, they can help improve depressive conditions [141].

As for safety, HIIT is characterized by being performed at high intensities, which, if not properly controlled, suggests offering a greater cardiovascular risk to individuals [142]. Therefore, it is suggested as preventive measures to assess the individual and family history, to know the level of physical activity and lifestyle, as well as possible risk factors, such as cardiovascular disease, hypertension or organ damage that will help to identify the degree of cardiovascular risk for each subject [143]. After screening, it is recommended for the elderly, to carry out medical evaluations and examinations [143-145]. After this process, we suggest that the HIIT training during the pandemic may be needed to be adapted for the trainer, building sessions with simpler exercises, with relatively low volumes (10-15 minutes), initially for three times a week, so that they can guarantee the safety, successful performance of the exercises, thus contributing to the continuity and positive adaptations of HIIT during the period of social distancing. Preventive care against COVID-19 infection should also be emphasized during this practice. Figure 1 summarizes the effects of sedentary behavior and physical inactivity, aerobic training, strength training, and HIIT on the physical and mental health of the elderly during social distancing caused by COVID-19.

\section{Conclusions and important home training considerations}

Both aerobic, strength and HIIT training are efficient methods to induce improvements in the overall mental and physical health of the elderly. It is worth mentioning that all methods of physical exercise must be adapted to the conditions of social distancing. Strategies should be created for the adherence of the elderly in home exercise programs, such as: promoting knowledge of the benefits of physical exercise; outlining daily routines and individual goals; choosing simple and accessible exercises; stimulating selfmonitoring; seeking environmental support factors, such as a safe space and monitoring through phone calls, video calls, with less frequent face-to-face meetings by a professional trained to prescribe physical exercise. Therefore, the type of method (aerobic, strength or HIIT training) must be used and planed previously together with the trainer, thus, enjoying the maximal of the potential benefits of each method of training.

\section{References}

[1] M.L. Holshue, C. DeBolt, S. Lindquist, K.H. Lofy, J. Wiesman, H. Bruce, C. Spitters, K. Ericson, S. Wilkerson, A. Tural, G. Diaz, A. Cohn, L. Fox, A. Patel, S.I. Gerber, L. Kim, S. Tong, X. Lu, S. Lindstrom, M.A. Pallansch, W.C. Weldon, H.M. Biggs, T.M. Uyeki, S.K. Pillai, Washington State 2019-nCoV Case Investigation Team, First Case of 2019 Novel Coronavirus in the United States, New England Journal of Medicine. 382 (10) (2020) 929-936. [DOI] [PubMed]

[2] Z. Wu, J.M. McGoogan, Characteristics of and Important Lessons from the Coronavirus Disease 2019 (COVID-19) Outbreak in China: Summary of a Report of 72314 Cases from the Chinese Center for Disease Control and Prevention, Journal of the American Medical Association, 323 (13) (2020) 1239-1242 [DOI] [PubMed]

[3] WHO, 2020, Coronavirus disease (COVID-19) - 
World Health Organization, https://www.who.int/emergencies/diseases/no vel-coronavirus-2019 (accessed March 08, 2021).

[4] J. Zheng, SARS-CoV-2: an Emerging Coronavirus that Causes a Global Threat, International Journal of Biology Sciences, 16 (10) (2020) 1678-1685. [DOI] [PubMed]

[5] J.A. de, F.N. Mesquita Fabiana, G. MarcondesBraga, M. Lidia Zytinski, F. André Melo e Silva de, F. Viviane Melo e Silva de, M.R. Ricardo, T. Evandro, Doença de Coronavírus-19 e o Miocárdio, Arq Bras Cardiol, 114 (2020). [DOI]

[6] G. Fung, H. Luo, Y. Qiu, D. Yang, B. McManus, Myocarditis, Circulation Research, 118 (3) (2016) 496-514. [DOI] [PubMed]

[7] N.C. Peeri, N. Shrestha, M.S. Rahman, R. Zaki, Z. Tan, S. Bibi, M. Baghbanzadeh, N. Aghamohammadi, W. Zhang, U. Haque, The SARS, MERS and novel coronavirus (COVID19) epidemics, the newest and biggest global health threats: what lessons have we learned?, International Journal of Epidemiology, (2020). [DOI] [PubMed]

[8] F. Zhou, T. Yu, R. Du, G. Fan, Y. Liu, Z. Liu, J. Xiang, Y. Wang, B. Song, X. Gu, L. Guan, Y. Wei, H. Li, X. Wu, J. Xu, S. Tu, Y. Zhang, H. Chen, B. Cao, Clinical course and risk factors for mortality of adult inpatients with COVID-19 in Wuhan, China: a retrospective cohort study, Lancet, 395 (10229) (2020) 1054-1062. [DOI] [PubMed]

[9] G. Onder, G. Rezza, S. Brusaferro, CaseFatality Rate and Characteristics of Patients Dying in Relation to COVID-19 in Italy, Journal of American Medical Society, 323(18) (2020) 1775-1776. [DOI] [PubMed]

[10] E.A. Holmes, R.C. O'Connor, V.H. Perry, I. Tracey, S. Wessely, L. Arseneault, C. Ballard, H. Christensen, R. Cohen Silver, I. Everall, T. Ford, A. John, T. Kabir, K. King, I. Madan, S. Michie, A.K. Przybylski, R. Shafran, A. Sweeney, C.M. Worthman, L. Yardley, K. Cowan, C. Cope, M. Hotopf, E. Bullmore, Multidisciplinary research priorities for the COVID-19 pandemic: a call for action for mental health science, The Lancet Psychiatry, 7 (6) (2020) 547-560. [DOI] [PubMed]

[11] P.S.F. Yip, Y.T. Cheung, P.H. Chau, Y.W. Law, The impact of epidemic outbreak: the case of severe acute respiratory syndrome (SARS) and suicide among older adults in Hong Kong, Crisis, 31 (2) (2010) 86-92.[DOI] [PubMed]

[12] L.A. Nickell, E.J. Crighton, C.S. Tracy, H. AlEnazy, Y. Bolaji, S. Hanjrah, A. Hussain, S. Makhlouf, R.E.G. Upshur, Psychosocial effects of SARS on hospital staff: survey of a large tertiary care institution, Canadian Medical Association Journal, 170 (5) (2004) 793-798. [DOI] [PubMed]

[13] M. Elovainio, C. Hakulinen, L. Pulkki-Råback, M. Virtanen, K. Josefsson, M. Jokela, J. Vahtera, M. Kivimäki, Contribution of risk factors to excess mortality in isolated and lonely individuals: an analysis of data from the UK Biobank cohort study, Lancet Public Health, 2 (6) (2017) 260-266. [DOI] [PubMed]

[14] T. Matthews, A. Danese, A. Caspi, H.L. Fisher, S. Goldman-Mellor, A. Kepa, T.E. Moffitt, C.L. Odgers, L. Arseneault, Lonely young adults in modern Britain: findings from an epidemiological cohort study, Psychological Medicine, 49 (2) (2019) 268-277. [DOI] [PubMed]

[15] D. Wasserman, R. van der Gaag, J. Wise, The term "physical distancing" is recommended rather than "social distancing" during the COVID-19 pandemic for reducing feelings of rejection among people with mental health problems. European Psychiatry, 63(1) (2020) E52. [DOI]

[16] D. Frasquilho, M.G. Matos, F. Salonna, D. Guerreiro, C.C. Storti, T. Gaspar, J.M. Caldasde-Almeida, Mental health outcomes in times of economic recession: a systematic literature review, BMC Public Health, 16 (115) (2016). [DOI] [PubMed]

[17] B. Barr, D. Taylor-Robinson, A. Scott-Samuel, M. McKee, D. Stuckler, Suicides associated with the 2008-10 economic recession in England: time trend analysis, BMJ, 345 (5142) (2012). [DOI] [PubMed]

[18] K.S. Dawson, R.A. Bryant, M. Harper, A. Kuowei Tay, A. Rahman, A. Schafer, M. van Ommeren, Problem Management Plus (PM+): a WHO transdiagnostic psychological intervention for common mental health problems, World Psychiatry, 14 (3) (2015) 354-357. [DOI] [PubMed]

[19] B.E. Hogan, W. Linden, B. Najarian, Social 
support interventions: do they work?, Clinical Psychology Review, 22 (3) (2002) 383-442. [DOI] [PubMed]

[20] S. Meunier, C. Roberge, S. Coulombe, J. Houle, Feeling better at work! Mental health selfmanagement strategies for workers with depressive and anxiety symptoms, Journal of Affective Disorders, 254 (2019) 7-14. [DOI] [PubMed]

[21] J.E. Shaw, R.A. Sicree, P.Z. Zimmet, Global estimates of the prevalence of diabetes for 2010 and 2030, Diabetes Researche and Clinical Practice, 87 (1) (2010) 4-14. [DOI] [PubMed]

[22] D.C. Nieman, Coronavirus disease-2019: A tocsin to our aging, unfit, corpulent, and immunodeficient society, Journal of Sport and Health Science, 9 (4) (2020) 293-301. [DOI] [PubMed]

[23] J.B. Ferreira-Júnior, E.D. Freitas, S.F. Chaves, Exercise: A Protective Measure or an "Open Window" for COVID-19? A Mini Review, Frontiers in Sports and Active Living, 2 (61) (2020) 61. [DOI] [PubMed]

[24] WHO, WHO I Active ageing: a policy framework, WHO. (2002). http://www.who.int/ageing/publications/active ageing/en/ (accessed March 08, 2021).

[25] A.J. Cruz-Jentoft, G. Bahat, J. Bauer, Y. Boirie, O. Bruyère, T. Cederholm, C. Cooper, F. Landi, Y. Rolland, A.A. Sayer, S.M. Schneider, C.C. Sieber, E. Topinkova, M. Vandewoude, M. Visser, M. Zamboni, and the E.G. for E. Writing Group for the European Working Group on Sarcopenia in Older People 2 (EWGSOP2), I. Bautmans, J.-P. Baeyens, M. Cesari, A. Cherubini, J. Kanis, M. Maggio, F. Martin, J.-P. Michel, K. Pitkala, J.-Y. Reginster, R. Rizzoli, D. Sánchez-Rodríguez, J. Schols, Sarcopenia: revised European consensus on definition and diagnosis, Age and Ageing, 48 (1) (2019) 1631. [DOI] [PubMed]

[26] A. Jawaid, Protecting older adults during social distancing, Science, 368 (6487) (2020) 145.1145. [DOI] [PubMed]

[27] P.C. Hallal, L.B. Andersen, F.C. Bull, R. Guthold, W. Haskell, U. Ekelund, Global physical activity levels: surveillance progress, pitfalls, and prospects, The Lancet, 380 (9838) (2012) 247-257. [DOI] [PubMed]
[28] A. Engin, The Definition and Prevalence of Obesity and Metabolic Syndrome, Advances in Experimental Medicine and Biology. 960 (1) (2017) 1-17. [DOI] [PubMed]

[29] V. Atmis, A. Yalcin, K. Silay, S. Ulutas, R. Bahsi, T. Turgut, D. Mut Sürmeli, H. Selvi Öztorun, S. Yaman, Ç. Çoşarderelioğlu, S. Aras, M. Varli, The relationship between allcause mortality sarcopenia and sarcopenic obesity among hospitalized older people, Aging Clinical and Experimental Research, 31 (11) (2019) 1563-1572. [DOI] [PubMed]

[30] S.L. James, D. Abate, K.H. Abate, S.M. Abay, C. Abbafati, N. Abbasi, H. Abbastabar, F. AbdAllah, J. Abdela, A. Abdelalim, I. Abdollahpour, R.S. Abdulkader, Z. Abebe, S.F. Abera, O.Z. Abil, H.N. Abraha, L.J. Abu-Raddad, N.M.E. Abu-Rmeileh, M.M.K. Accrombessi, D. Acharya, P. Acharya, I.N. Ackerman, A.A. Adamu, O.M. Adebayo, V. Adekanmbi, O.O. Adetokunboh, M.G. Adib, J.C. Adsuar, K.A. Afanvi, M. Afarideh, A. Afshin, G. Agarwal, K.M. Agesa, R. Aggarwal, S.A. Aghayan, S. Agrawal, A. Ahmadi, M. Ahmadi, H. Ahmadieh, M.B. Ahmed, A.N. Aichour, I. Aichour, M.T.E. Aichour, T. Akinyemiju, N. Akseer, Z. Al-Aly, A. Al-Eyadhy, H.M. Al-Mekhlafi, R.M. Al-Raddadi, F. Alahdab, K. Alam, T. Alam, A. Alashi, S.M. Alavian, K.A. Alene, M. Alijanzadeh, R. Alizadeh-Navaei, S.M. Aljunid, A. Alkerwi, F. Alla, P. Allebeck, M.M.L. Alouani, K. Altirkawi, N. Alvis-Guzman, A.T. Amare, L.N. Aminde, W. Ammar, Y.A. Amoako, N.H. Anber, C.L. Andrei, S. Androudi, M.D. Animut, M. Anjomshoa, M.G. Ansha, C.A.T. Antonio, P. Anwari, J. Arabloo, A. Arauz, O. Aremu, F. Ariani, B. Armoon, J. Ärnlöv, A. Arora, A. Artaman, K.K. Aryal, H. Asayesh, R.J. Asghar, Z. Ataro, S.R. Atre, M. Ausloos, L. Avila-Burgos, E.F.G.A. Avokpaho, A. Awasthi, B.P.A. Quintanilla, R. Ayer, P.S. Azzopardi, A. Babazadeh, H. Badali, A. Badawi, A.G. Bali, K.E. Ballesteros, S.H. Ballew, M. Banach, J.A.M. Banoub, A. Banstola, A. Barac, M.A. Barboza, S.L. Barker-Collo, T.W. Bärnighausen, L.H. Barrero, B.T. Baune, S. Bazargan-Hejazi, N. Bedi, E. Beghi, M. Behzadifar, M. Behzadifar, Y. Béjot, A.B. Belachew, Y.A. Belay, M.L. Bell, A.K. Bello, I.M. Bensenor, E. Bernabe, R.S. Bernstein, M. Beuran, T. Beyranvand, N. Bhala, S. Bhattarai, S. Bhaumik, Z.A. Bhutta, B. Biadgo, A. Bijani, 
B. Bikbov, V. Bilano, N. Bililign, M.S.B. Sayeed, D. Bisanzio, B.F. Blacker, F.M. Blyth, I.R. BouOrm, S. Boufous, R. Bourne, O.J. Brady, M. Brainin, L.C. Brant, A. Brazinova, N.J.K. Breitborde, H. Brenner, P.S. Briant, A.M. Briggs, A.N. Briko, G. Britton, T. Brugha, R. Buchbinder, R. Busse, Z.A. Butt, L. CahuanaHurtado, J. Cano, R. Cárdenas, J.J. Carrero, A. Carter, F. Carvalho, C.A. Castañeda-Orjuela, J.C. Rivas, F. Castro, F. Catalá-López, K.M. Cercy, E. Cerin, Y. Chaiah, A.R. Chang, H.-Y. Chang, J.-C. Chang, F.J. Charlson, A. Chattopadhyay, V.K. Chattu, P. Chaturvedi, P.P.-C. Chiang, K.L. Chin, A. Chitheer, J.-Y.J. Choi, R. Chowdhury, H. Christensen, D.J. Christopher, F.M. Cicuttini, L.G. Ciobanu, M. Cirillo, R.M. Claro, D. Collado-Mateo, C. Cooper, J. Coresh, P.A. Cortesi, M. Cortinovis, M. Costa, E. Cousin, M.H. Criqui, E.A. Cromwell, M. Cross, J.A. Crump, A.F. Dadi, L. Dandona, R. Dandona, P.I. Dargan, A. Daryani, R.D. Gupta, J.D. Neves, T.T. Dasa, G. Davey, A.C. Davis, D.V. Davitoiu, B.D. Courten, F.P.D.L. Hoz, D.D. Leo, J.-W.D. Neve, M.G. Degefa, L. Degenhardt, S. Deiparine, R.P. Dellavalle, G.T. Demoz, K. Deribe, N. Dervenis, D.C.D. Jarlais, G.A. Dessie, S. Dey, S.D. Dharmaratne, M.T. Dinberu, M.A. Dirac, S. Djalalinia, L. Doan, K. Dokova, D.T. Doku, E.R. Dorsey, K.E. Doyle, T.R. Driscoll, M. Dubey, E. Dubljanin, E.E. Duken, B.B. Duncan, A.R. Duraes, H. Ebrahimi, S. Ebrahimpour, M.M. Echko, D. Edvardsson, A. Effiong, J.R. Ehrlich, C.E. Bcheraoui, M.E.S. Zaki, Z. El-Khatib, H. Elkout, I.R.F. Elyazar, A. Enayati, A.Y. Endries, B. Er, H.E. Erskine, B. Eshrati, S. Eskandarieh, A. Esteghamati, S. Esteghamati, H. Fakhim, V.F. Omrani, M. Faramarzi, M. Fareed, F. Farhadi, T.A. Farid, C.S.E. sá Farinha, A. Farioli, A. Faro, M.S. Farvid, F. Farzadfar, V.L. Feigin, N. Fentahun, S.-M. Fereshtehnejad, E. Fernandes, J.C. Fernandes, A.J. Ferrari, G.T. Feyissa, I. Filip, F. Fischer, C. Fitzmaurice, N.A. Foigt, K.J. Foreman, J. Fox, T.D. Frank, T. Fukumoto, N. Fullman, T. Fürst, J.M. Furtado, N.D. Futran, S. Gall, M. Ganji, F.G. Gankpe, A.L. Garcia-Basteiro, W.M. Gardner, A.K. Gebre, A.T. Gebremedhin, T.G. Gebremichael, T.F. Gelano, J.M. Geleijnse, R. GenovaMaleras, Y.C.D. Geramo, P.W. Gething, K.E. Gezae, K. Ghadiri, K.G. Falavarjani, M. Ghasemi-Kasman, M. Ghimire, R. Ghosh, A.G.
Ghoshal, S. Giampaoli, P.S. Gill, T.K. Gill, I.A. Ginawi, G. Giussani, E.V. Gnedovskaya, E.M. Goldberg, S. Goli, H. Gómez-Dantés, P.N. Gona, S.V. Gopalani, T.M. Gorman, A.C. Goulart, B.N.G. Goulart, A. Grada, M.E. Grams, G. Grosso, H.C. Gugnani, Y. Guo, P.C. Gupta, R. Gupta, R. Gupta, T. Gupta, B. Gyawali, J.A. Haagsma, V. Hachinski, N. Hafezi-Nejad, H.H. Bidgoli, T.B. Hagos, G.B. Hailu, A. HajMirzaian, A. Haj-Mirzaian, R.R. Hamadeh, S. Hamidi, A.J. Handal, G.J. Hankey, Y. Hao, H.L. Harb, S. Harikrishnan, J.M. Haro, M. Hasan, H. Hassankhani, H.Y. Hassen, R. Havmoeller, C.N. Hawley, R.J. Hay, S.I. Hay, A. HedayatizadehOmran, B. Heibati, D. Hendrie, A. Henok, C. Herteliu, S. Heydarpour, D.T. Hibstu, H.T. Hoang, H.W. Hoek, H.J. Hoffman, M.K. Hole, E.H. Rad, P. Hoogar, H.D. Hosgood, S.M. Hosseini, M. Hosseinzadeh, M. Hostiuc, S. Hostiuc, P.J. Hotez, D.G. Hoy, M. Hsairi, A.S. Htet, G. Hu, J.J. Huang, C.K. Huynh, K.M. Iburg, C.T. Ikeda, B. Ileanu, O.S. Ilesanmi, U. Iqbal, S.S.N. Irvani, C.M.S. Irvine, S.M.S. Islam, F. Islami, K.H. Jacobsen, L. Jahangiry, N. Jahanmehr, S.K. Jain, M. Jakovljevic, M. Javanbakht, A.U. Jayatilleke, P. Jeemon, R.P. Jha, V. Jha, J.S. Ji, C.O. Johnson, J.B. Jonas, J.J. Jozwiak, S.B. Jungari, M. Jürisson, Z. Kabir, R. Kadel, A. Kahsay, R. Kalani, T. Kanchan, M. Karami, B.K. Matin, A. Karch, C. Karema, N. Karimi, S.M. Karimi, A. Kasaeian, D.H. Kassa, G.M. Kassa, T.D. Kassa, N.J. Kassebaum, S.V. Katikireddi, N. Kawakami, A.K. Karyani, M.M. Keighobadi, P.N. Keiyoro, L. Kemmer, G.R. Kemp, A.P. Kengne, A. Keren, Y.S. Khader, B. Khafaei, M.A. Khafaie, A. Khajavi, I.A. Khalil, E.A. Khan, M.S. Khan, M.A. Khan, Y.-H. Khang, M. Khazaei, A.T. Khoja, A. Khosravi, M.H. Khosravi, A.A. Kiadaliri, D.N. Kiirithio, C.-I. Kim, D. Kim, P. Kim, Y.-E. Kim, Y.J. Kim, R.W. Kimokoti, Y. Kinfu, A. Kisa, K. KissimovaSkarbek, M. Kivimäki, A.K.S. Knudsen, J.M. Kocarnik, S. Kochhar, Y. Kokubo, T. Kolola, J.A. Kopec, S. Kosen, G.A. Kotsakis, P.A. Koul, A. Koyanagi, M.A. Kravchenko, K. Krishan, K.J. Krohn, B.K. Defo, B.K. Bicer, G.A. Kumar, M. Kumar, H.H. Kyu, D.P. Lad, S.D. Lad, A. Lafranconi, R. Lalloo, T. Lallukka, F.H. Lami, V.C. Lansingh, A. Latifi, K.M.-M. Lau, J.V. Lazarus, J.L. Leasher, J.R. Ledesma, P.H. Lee, J. Leigh, J. Leung, M. Levi, S. Lewycka, S. Li, Y. Li, Y. Liao, M.L. Liben, L.-L. Lim, S.S. Lim, S. 
Liu, R. Lodha, K.J. Looker, A.D. Lopez, S. Lorkowski, P.A. Lotufo, N. Low, R. Lozano, T.C.D. Lucas, L.R. Lucchesi, R. Lunevicius, R.A. Lyons, S. Ma, E.R.K. Macarayan, M.T. Mackay, F. Madotto, H.M.A.E. Razek, M.M.A.E. Razek, D.P. Maghavani, N.B. Mahotra, H.T. Mai, M. Majdan, R. Majdzadeh, A. Majeed, R. Malekzadeh, D.C. Malta, A.A. Mamun, A.-L. Manda, H. Manguerra, T. Manhertz, M.A. Mansournia, L.G. Mantovani, C.C. Mapoma, J.C. Maravilla, W. Marcenes, A. Marks, F.R. Martins-Melo, I. Martopullo, W. März, M.B. Marzan, T.P. Mashamba-Thompson, B.B. Massenburg, M.R. Mathur, K. Matsushita, P.K. Maulik, M. Mazidi, C. McAlinden, J.J. McGrath, M. McKee, M.M. Mehndiratta, R. Mehrotra, K.M. Mehta, V. Mehta, F. Mejia-Rodriguez, T. Mekonen, A. Melese, M. Melku, M. Meltzer, P.T.N. Memiah, Z.A. Memish, W. Mendoza, D.T. Mengistu, G. Mengistu, G.A. Mensah, S.T. Mereta, A. Meretoja, T.J. Meretoja, T. Mestrovic, N.M.G. Mezerji, B. Miazgowski, T. Miazgowski, A.I. Millear, T.R. Miller, B. Miltz, G.K. Mini, M. Mirarefin, E.M. Mirrakhimov, A.T. Misganaw, P.B. Mitchell, H. Mitiku, B. Moazen, B. Mohajer, K.A. Mohammad, N. Mohammadifard, M. Mohammadnia-Afrouzi, M.A. Mohammed, S. Mohammed, F. Mohebi, M. Moitra, A.H. Mokdad, M. Molokhia, L. Monasta, Y. Moodley, M. Moosazadeh, G. Moradi, M. Moradi-Lakeh, M. Moradinazar, P. Moraga, L. Morawska, I.M. Velásquez, J. Morgado-Da-Costa, S.D. Morrison, M.M. Moschos, W.C. Mountjoy-Venning, S.M. Mousavi, K.B. Mruts, A.A. Muche, K.F. Muchie, U.O. Mueller, O.S. Muhammed, S. Mukhopadhyay, K. Muller, J.E. Mumford, M. Murhekar, J. Musa, K.I. Musa, G. Mustafa, A.F. Nabhan, C. Nagata, M. Naghavi, A. Naheed, A. Nahvijou, G. Naik, N. Naik, F. Najafi, L. Naldi, H.S. Nam, V. Nangia, J.R. Nansseu, B.R. Nascimento, G. Natarajan, N. Neamati, I. Negoi, R.I. Negoi, S. Neupane, C.R.J. Newton, J.W. Ngunjiri, A.Q. Nguyen, H.T. Nguyen, H.L.T. Nguyen, H.T. Nguyen, L.H. Nguyen, M. Nguyen, N.B. Nguyen, S.H. Nguyen, E. Nichols, D.N.A. Ningrum, M.R. Nixon, N. Nolutshungu, S. Nomura, O.F. Norheim, M. Noroozi, B. Norrving, J.J. Noubiap, H.R. Nouri, M.N. Shiadeh, M.R. Nowroozi, E.O. Nsoesie, P.S. Nyasulu, C.M. Odell, R. Ofori-Asenso, F.A. Ogbo, I.-H. Oh, O. Oladimeji, A.T. Olagunju,
T.O. Olagunju, P.R. Olivares, H.E. Olsen, B.O. Olusanya, K.L. Ong, S.K. Ong, E. Oren, A. Ortiz, E. Ota, S.S. Otstavnov, S. Øverland, M.O. Owolabi, M.P. A, R. Pacella, A.H. Pakpour, A. Pana, S. Panda-Jonas, A. Parisi, E.K. Park, C.D.H. Parry, S. Patel, S. Pati, S.T. Patil, A. Patle, G.C. Patton, V.R. Paturi, K.R. Paulson, N. Pearce, D.M. Pereira, N. Perico, K. Pesudovs, H.Q. Pham, M.R. Phillips, D.M. Pigott, J.D. Pillay, M.A. Piradov, M. Pirsaheb, F. Pishgar, O. Plana-Ripoll, D. Plass, S. Polinder, S. Popova, M.J. Postma, A. Pourshams, H. Poustchi, D. Prabhakaran, S. Prakash, V. Prakash, C.A. Purcell, M.B. Purwar, M. Qorbani, D.A. Quistberg, A. Radfar, A. Rafay, A. Rafiei, F. Rahim, K. Rahimi, A. Rahimi-Movaghar, V. Rahimi-Movaghar, M. Rahman, M.H. ur Rahman, M.A. Rahman, S.U. Rahman, R.K. Rai, F. Rajati, U. Ram, P. Ranjan, A. Ranta, P.C. Rao, D.L. Rawaf, S. Rawaf, K.S. Reddy, R.C. Reiner, N. Reinig, M.B. Reitsma, G. Remuzzi, A.M.N. Renzaho, S. Resnikoff, S. Rezaei, M.S. Rezai, A.L.P. Ribeiro, N.L.S. Roberts, S.R. Robinson, L. Roever, L. Ronfani, G. Roshandel, A. Rostami, G.A. Roth, A. Roy, E. Rubagotti, P.S. Sachdev, N. Sadat, B. Saddik, E. Sadeghi, S.S. Moghaddam, H. Safari, Y. Safari, R. Safari-Faramani, M. Safdarian, S. Safi, S. Safiri, R. Sagar, A. Sahebkar, M.A. Sahraian, H.S. Sajadi, N. Salam, J.S. Salama, P. Salamati, K. Saleem, Z. Saleem, Y. Salimi, J.A. Salomon, S.S. Salvi, I. Salz, A.M. Samy, J. Sanabria, Y. Sang, D.F. Santomauro, I.S. Santos, J.V. Santos, M.M.S. Milicevic, B.P.S. Jose, M. Sardana, A.R. Sarker, N. Sarrafzadegan, B. Sartorius, S. Sarvi, B. Sathian, M. Satpathy, A.R. Sawant, M. Sawhney, S. Saxena, M. Saylan, E. Schaeffner, M.I. Schmidt, I.J.C. Schneider, B. Schöttker, D.C. Schwebel, F. Schwendicke, J.G. Scott, M. Sekerija, S.G. Sepanlou, E. Serván-Mori, S. Seyedmousavi, H. Shabaninejad, A. Shafieesabet, M. Shahbazi, A.A. Shaheen, M.A. Shaikh, M. Shams-Beyranvand, M. Shamsi, M. Shamsizadeh, H. Sharafi, K. Sharafi, M. Sharif, M. Sharif-Alhoseini, M. Sharma, R. Sharma, J. She, A. Sheikh, P. Shi, K. Shibuya, M. Shigematsu, R. Shiri, R. Shirkoohi, K. Shishani, I. Shiue, F. Shokraneh, H. Shoman, M.G. Shrime, S. Si, S. Siabani, T.J. Siddiqi, I.D. Sigfusdottir, R. Sigurvinsdottir, J.P. Silva, D.G.A. Silveira, N.S.V. Singam, J.A. Singh, N.P. 
Singh, V. Singh, D.N. Sinha, E. Skiadaresi, E.L.N. Slepak, K. Sliwa, D.L. Smith, M. Smith, A.M.S. Filho, B.H. Sobaih, S. Sobhani, E. Sobngwi, S.S. Soneji, M. Soofi, M. Soosaraei, R.J.D. Sorensen, J.B. Soriano, I.N. Soyiri, L.A. Sposato, C.T. Sreeramareddy, V. Srinivasan, J.D. Stanaway, D.J. Stein, C. Steiner, T.J. Steiner, M.A. Stokes, L.J. Stovner, M.L. Subart, A. Sudaryanto, M.B. Sufiyan, B.F. Sunguya, P.J. Sur, I. Sutradhar, B.L. Sykes, D.O. Sylte, R. Tabarés-Seisdedos, S.K. Tadakamadla, B.T. Tadesse, N. Tandon, S.G. Tassew, M. Tavakkoli, N. Taveira, H.R. Taylor, A. TehraniBanihashemi, T.G. Tekalign, S.W. Tekelemedhin, M.G. Tekle, H. Temesgen, M.H. Temsah, O. Temsah, A.S. Terkawi, M. Teweldemedhin, K.R. Thankappan, N. Thomas, B. Tilahun, Q.G. To, M. Tonelli, R. ToporMadry, F. Topouzis, A.E. Torre, M. TortajadaGirbés, M. Touvier, M.R. Tovani-Palone, J.A. Towbin, B.X. Tran, K.B. Tran, C.E. Troeger, T.C. Truelsen, M.K. Tsilimbaris, D. Tsoi, L.T. Car, E.M. Tuzcu, K.N. Ukwaja, I. Ullah, E.A. Undurraga, J. Unutzer, R.L. Updike, M.S. Usman, O.A. Uthman, M. Vaduganathan, A. Vaezi, P.R. Valdez, S. Varughese, T.J. Vasankari, N. Venketasubramanian, S. Villafaina, F.S. Violante, S.K. Vladimirov, V. Vlassov, S.E. Vollset, K. Vosoughi, I.S. Vujcic, F.S. Wagnew, Y. Waheed, S.G. Waller, Y. Wang, Y.-P. Wang, E. Weiderpass, R.G. Weintraub, D.J. Weiss, F. Weldegebreal, K.G. Weldegwergs, A. Werdecker, T.E. West, H.A. Whiteford, J. Widecka, T. Wijeratne, L.B. Wilner, S. Wilson, A.S. Winkler, A.B. Wiyeh, C.S. Wiysonge, C.D.A. Wolfe, A.D. Woolf, S. Wu, Y.-C. Wu, G.M.A. Wyper, D. Xavier, G. Xu, S. Yadgir, A. Yadollahpour, S.H.Y. Jabbari, T. Yamada, L.L. Yan, Y. Yano, M. Yaseri, Y.J. Yasin, A. Yeshaneh, E.M. Yimer, P. Yip, E. Yisma, N. Yonemoto, S.-J. Yoon, M. Yotebieng, M.Z. Younis, M. Yousefifard, C. Yu, V. Zadnik, Z. Zaidi, S.B. Zaman, M. Zamani, Z. Zare, A.J. Zeleke, Z.M. Zenebe, K. Zhang, Z. Zhao, M. Zhou, S. Zodpey, I. Zucker, T. Vos, C.J.L. Murray, Global, regional, and national incidence, prevalence, and years lived with disability for 354 diseases and injuries for 195 countries and territories, 1990-2017: a systematic analysis for the Global Burden of Disease Study 2017, The Lancet, 392 (10159) (2018) 1789-1858. [DOI] [PubMed]
[31] T. Kelly, W. Yang, C.-S. Chen, K. Reynolds, J. $\mathrm{He}$, Global burden of obesity in 2005 and projections to 2030, International Journal of Obesity, 32 (9) (2008) 1431-1437._ [DOI] [PubMed]

[32] Z.J. Ward, S.N. Bleich, A.L. Cradock, J.L. Barrett, C.M. Giles, C. Flax, M.W. Long, S.L. Gortmaker, Projected U.S. State-Level Prevalence of Adult Obesity and Severe Obesity, New England Journal of Medicine, 381 (25) (2019) 2440-2450. [DOI] [PubMed]

[33] H. Roschel, G.G. Artioli, B. Gualano, Risk of Increased Physical Inactivity During COVID -19 Outbreak in Older People: A Call for Actions, Journal of the American Geriatrics Society, 68 (2020) 1126-1128. [DOI] [PubMed]

[34] T. Henry, D.M. Monack, Activation of the inflammasome upon Francisella tularensis infection: interplay of innate immune pathways and virulence factors, Cellular Microbiology, 9 (6) (2007) 2543-2551. [DOI] [PubMed]

[35] M.G. Ramos Muniz, M. Palfreeman, N. Setzu, M.A. Sanchez, P. Saenz Portillo, K.M. Garza, K.L. Gosselink, C.T. Spencer, Obesity Exacerbates the Cytokine Storm Elicited by Francisella tularensis Infection of Females and Is Associated with Increased Mortality, Biomed Research Internatioanl, 2018 (2018). [DOI] [PubMed]

[36] A. Rebelo-Marques, A. De Sousa Lages, R. Andrade, C.F. Ribeiro, A. Mota-Pinto, F. Carrilho, J. Espregueira-Mendes, Aging Hallmarks: The Benefits of Physical Exercise, Frontiers in Endocrinology, 9 (2018). [DOI] [PubMed]

[37] F.J.G. Pitanga, C.C. Beck, C.P.S. Pitanga, Physical Activity and Reducing Sedentary Behavior During The Coronavirus Pandemic, Arquivos Brasileiros de Cardiologia, (2020). [DOI] [PubMed]

[38] FITBIT, The Impact Of Coronavirus On Global Activity, Fitbit Blog, (2020).

[39] L. Goethals, N. Barth, J. Guyot, D. Hupin, T. Celarier, B. Bongue, Impact of Home Quarantine on Physical Activity Among Older Adults Living at Home During the COVID-19 Pandemic: Qualitative Interview Study, Journal of Medical Internet Research Aging, 3 (1) (2020) e19007. [DOI] [PubMed] 
[40] K.A. Bowden Davies, S. Pickles, V.S. Sprung, G.J. Kemp, U. Alam, D.R. Moore, A.A. Tahrani, D.J. Cuthbertson, Reduced physical activity in young and older adults: metabolic and musculoskeletal implications, Therapeutic Advances in Endocrinology, 10 (2019) 2042018819888824. [DOI] [PubMed]

[41] L. Breen, K.A. Stokes, T.A. Churchward-Venne, D.R. Moore, S.K. Baker, K. Smith, P.J. Atherton, S.M. Phillips, Two weeks of reduced activity decreases leg lean mass and induces "anabolic resistance" of myofibrillar protein synthesis in healthy elderly, Journal of Clinical Endocrinology Metabolism, 98 (6) (2013) 2604-2612. [DOI] [PubMed]

[42] K. Ibrahim, C. May, H.P. Patel, M. Baxter, A.A. Sayer, H. Roberts, A feasibility study of implementing grip strength measurement into routine hospital practice (GRImP): study protocol, Pilot and Feasibility Studies, 2 (2016). [DOI] [PubMed]

[43] F. Buckinx, F. Landi, M. Cesari, R.A. Fielding, M. Visser, K. Engelke, S. Maggi, E. Dennison, N.M. Al-Daghri, S. Allepaerts, J. Bauer, I. Bautmans, M.L. Brandi, O. Bruyère, T. Cederholm, F. Cerreta, A. Cherubini, C. Cooper, A. Cruz-Jentoft, E. McCloskey, B. Dawson-Hughes, J.-M. Kaufman, A. Laslop, J. Petermans, J.-Y. Reginster, R. Rizzoli, S. Robinson, Y. Rolland, R. Rueda, B. Vellas, J.A. Kanis, Pitfalls in the measurement of muscle mass: a need for a reference standard, Journal of Cachexia Sarcopenia and Muscle, 9 (2018) 269-278. [DOI] [PubMed]

[44] E. Treviño-Aguirre, T. López-Teros, L. Gutiérrez-Robledo, M. Vandewoude, M. PérezZepeda, Availability and use of dual energy Xray absorptiometry (DXA) and bio-impedance analysis (BIA) for the evaluation of sarcopenia by Belgian and Latin American geriatricians, J Cachexia Sarcopenia Muscle, 5 (2) (2014) 7981. [DOI] [PubMed]

[45] M. J, Carvalho, E. Marques, J. Mota, Training and detraining effects on functional fitness after a multicomponent training in older women, Gerontology, 55 (1) (2009) 41-48. [DOI] [PubMed]

[46] P. Aagaard, C. Suetta, P. Caserotti, S.P. Magnusson, M. Kjaer, Role of the nervous system in sarcopenia and muscle atrophy with aging: strength training as a countermeasure, Scandinavian Journal of Medicine Science and Sports, 20 (1) (2010) 49-64. [DOI] [PubMed]

[47] A.B. Newman, V. Kupelian, M. Visser, E.M. Simonsick, B.H. Goodpaster, S.B. Kritchevsky, F.A. Tylavsky, S.M. Rubin, T.B. Harris, Strength, but not muscle mass, is associated with mortality in the health, aging and body composition study cohort, The Journal of Gerontology Series A Biological Sciences and Medical Sciences, 61 (1) (2006) 72-77. [DOI] [PubMed]

[48] I. Mujika, S. Padilla, Detraining: loss of training-induced physiological and performance adaptations. Part I: short term insufficient training stimulus, Sports Medicine. 30 (2) (2000) 79-87. [DOI] [PubMed]

[49] T.R. Henwood, D.R. Taaffe, Detraining and retraining in older adults following long-term muscle power or muscle strength specific training, The Journal of Gerontology Series A: Biology Science Medicine, 63 (7) (2008) 751758. [DOI] [PubMed]

[50] N.B. McKinnon, D.M. Connelly, C.L. Rice, S.W. Hunter, T.J. Doherty, Neuromuscular contributions to the age-related reduction in muscle power: Mechanisms and potential role of high velocity power training, Ageing Research Reviews, 35 (2017) 147-154. [DOI] [PubMed]

[51] M. Weston, K.L. Taylor, A.M. Batterham, W.G. Hopkins, Effects of low-volume high-intensity interval training (HIT) on fitness in adults: a meta-analysis of controlled and non-controlled trials, Sports Medicine, 44 (7) (2014) 10051017. [DOI] [PubMed]

[52] X. Lin, S.M. Alvim, E.J. Simoes, I.M. Bensenor, S.M. Barreto, M.I. Schmidt, A.L. Ribeiro, F. Pitanga, M.C.C. Almeida, S. Liu, P.A. Lotufo, Leisure Time Physical Activity and CardioMetabolic Health: Results From the Brazilian Longitudinal Study of Adult Health (ELSABrasil), Journal of American Heart Association, 5 (6) (2016). [DOI] [PubMed]

[53] M. Sellami, M. Gasmi, J. Denham, L.D. Hayes, D. Stratton, J. Padulo, N. Bragazzi, Effects of Acute and Chronic Exercise on Immunological Parameters in the Elderly Aged: Can Physical Activity Counteract the Effects of Aging? Frontiers in Immunology, 9 (2187) (2018). 
[DOI] [PubMed]

[54] B. Vandanmagsar, Y.-H. Youm, A. Ravussin, J.E. Galgani, K. Stadler, R.L. Mynatt, E. Ravussin, J.M. Stephens, V.D. Dixit, The NLRP3 inflammasome instigates obesity-induced inflammation and insulin resistance, Nature Medicine, 17 (2) (2011) 179-188. [DOI] [PubMed]

[55] WHO, WHO | Mental health: a state of wellbeing, WHO. (n.d.). http://origin.who.int/features/factfiles/mental_ health/en/ (accessed June 29, 2020).

[56] WHO, Mental disorders, (2019). https://www.who.int/news-room/fact-

sheets/detail/mental-disorders (accessed March 08, 2021).

[57] R.C. Kessler, S. Aguilar-Gaxiola, J. Alonso, S. Chatterji, S. Lee, J. Ormel, T.B. Üstün, P.S. Wang, The global burden of mental disorders: An update from the WHO World Mental Health (WMH) Surveys, Epidemiology Psichiatry Society, 18 (1) (2009) 23-33. [DOI] [PubMed]

[58] C. Demont-Heinrich, The Association Between Physical Activity, Mental Health and Quality of Life: A Population-Based Study, 79 (2009).

[59] WHO, WHO-Physical Exercise concept, WHO. (2020).

http://www.who.int/dietphysicalactivity/pa/en/ (accessed March 08, 2021).

[60] A. Simonnet, M. Chetboun, J. Poissy, V. Raverdy, J. Noulette, A. Duhamel, J. Labreuche, D. Mathieu, F. Pattou, M. Jourdain, LICORN and the Lille COVID-19 and Obesity study group, High Prevalence of Obesity in Severe Acute Respiratory Syndrome Coronavirus-2 (SARS-CoV-2) Requiring Invasive Mechanical Ventilation, Obesity (Silver Spring), 28 (7) (2020) 1195-1199. [DOI] [PubMed]

[61] C.J. Caspersen, K.E. Powell, G.M. Christenson, Physical activity, exercise, and physical fitness: definitions and distinctions for health-related research, Public Health Rep. 100 (1985) 126131. [PubMed]

[62] G.A. Kelley, K.S. Kelley, Exercise and sleep: a systematic review of previous meta-analyses, Journal of Evidence Based Medicine, 10 (2) (2017) 26-36. [DOI] [PubMed]

[63] O. Lederman, P.B. Ward, J. Firth, C. Maloney,
R. Carney, D. Vancampfort, B. Stubbs, M. Kalucy, S. Rosenbaum, Does exercise improve sleep quality in individuals with mental illness? A systematic review and meta-analysis, Journal of Psychiatry Researc, 109 (1) (2019) 96-106. [DOI] [PubMed]

[64] D. Lubans, J. Richards, C. Hillman, G. Faulkner, M. Beauchamp, M. Nilsson, P. Kelly, J. Smith, L. Raine, S. Biddle, Physical Activity for Cognitive and Mental Health in Youth: A Systematic Review of Mechanisms, Pediatrics, 138 (3) (2016). [DOI] [PubMed]

[65] M. Hamer, Y. Chida, Physical activity and risk of neurodegenerative disease: a systematic review of prospective evidence, Psychological Medicine, 39 (1) (2009) 3-11. [DOI] [PubMed]

[66] J. Woods, N.T. Hutchinson, S.K. Powers, W.O. Roberts, M.C. Gomez-Cabrera, Z. Radak, I. Berkes, A. Boros, I. Boldogh, C. Leeuwenburgh, H.J. Coelho-Júnior, E. Marzetti, Y. Cheng, J. Liu, J.L. Durstine, J. Sun, L.L. Ji, The COVID-19 Pandemic and Physical Activity, Sports Medicine and Health Science, (2020). [DOI]

[67] ACSM, (2014) ACSM's guidelines for exercise testing and prescription, Lippincott Williams \& Wilkins,

[68] D.C. Nieman, Exercise, infection, and immunity, International Journal of Sports Medicine, 15 (1994) 131-141. [DOI] [PubMed]

[69] D.C. Nieman, S.L. Nehlsen-Cannarella, The effects of acute and chronic exercise of immunoglobulins, Sports Medicine, 11 (3) (1991) 183-201. [DOI] [PubMed]

[70] D.C. Nieman, D.A. Henson, G. Gusewitch, B.J. Warren, R.C. Dotson, D.E. Butterworth, S.L. Nehlsen-Cannarella, Physical activity and immune function in elderly women, Medicine Science and Sports Exercise. 25 (7) 823-831. [DOI] [PubMed]

[71] D.M. Crist, L.T. Mackinnon, R.F. Thompson, H.A. Atterbom, P.A. Egan, Physical exercise increases natural cellular-mediated tumor cytotoxicity in elderly women, Gerontology, 35 (3) (1989) 66-71. [DOI] [PubMed]

[72] M.A. Fiatarone, J.E. Morley, E.T. Bloom, D. Benton, G.F. Solomon, T. Makinodan, The effect of exercise on natural killer cell activity in young and old subjects, Journal of 
Gerontology, 44 (2-3) (1989) M37-45. [DOI] [PubMed]

[73] L.H. Colbert, M. Visser, E.M. Simonsick, R.P. Tracy, A.B. Newman, S.B. Kritchevsky, M. Pahor, D.R. Taaffe, J. Brach, S. Rubin, T.B. Harris, Physical activity, exercise, and inflammatory markers in older adults: findings from the Health, Aging and Body Composition Study, Journal of American Geriatrics Society, 52 (7) (2004) 1098-1104. [DOI] [PubMed]

[74] L.C.R. Silva, A.L. de Araújo, J.R. Fernandes, M. de S.T. Matias, P.R. Silva, A.J.S. Duarte, L.E. Garcez Leme, G. Benard, Moderate and intense exercise lifestyles attenuate the effects of aging on telomere length and the survival and composition of $T$ cell subpopulations, Age (Dordr), 38 (1) (2016). [DOI] [PubMed]

[75] J.A. Woods, M.A. Ceddia, B.W. Wolters, J.K. Evans, Q. Lu, E. McAuley, Effects of 6 months of moderate aerobic exercise training on immune function in the elderly, Mechanisms of Ageing and Development, 109 (1) (1999) 119. [DOI] [PubMed]

[76] H. Yan, A. Kuroiwa, H. Tanaka, M. Shindo, A. Kiyonaga, A. Nagayama, Effect of moderate exercise on immune senescence in men, European Journal of Applied Physiology, 86 (2001) 105-111. [DOI] [PubMed]

[77] N.A. Duggal, G. Niemiro, S.D. Harridge, R.J. Simpson, J.M. Lord, Can physical activity ameliorate immunosenescence and thereby reduce age-related multi-morbidity?, Nature Reviews Immunology, 19 (2) (2019) 563-572. [DOI] [PubMed]

[78] M.L. Kohut, B.A. Arntson, W. Lee, K. Rozeboom, K.-J. Yoon, J.E. Cunnick, J. McElhaney, Moderate exercise improves antibody response to influenza immunization in older adults, Vaccine, 22 (9) (2004) 22982306. [DOI] [PubMed]

[79] J.I. Webster, L. Tonelli, E.M. Sternberg, Neuroendocrine regulation of immunity, Annual Review of Immunology, 20 (2002) 125-163. [DOI] [PubMed]

[80] Z.F. Kapasi, P.A. Catlin, J. Beck, T. Roehling, K. Smith, The role of endogenous opioids in moderate exercise training-induced enhancement of the secondary antibody response in mice, Physical Therapy, 81 (11) (2001) 1801-1809. [PubMed]
[81] P.-Y. Yang, K.-H. Ho, H.-C. Chen, M.-Y. Chien, Exercise training improves sleep quality in middle-aged and older adults with sleep problems: a systematic review, Journal of Physiotherapy, 58 (3) (2012) 157-163. [DOI] [PubMed]

[82] W. Bouaziz, T. Vogel, E. Schmitt, G. Kaltenbach, B. Geny, P.O. Lang, Health benefits of aerobic training programs in adults aged 70 and over: a systematic review, Archives of Gerontology and Geriatrics, 69 (2017) 110-127. [DOI] [PubMed]

[83] M. Ploughman, L.P. Kelly, Four birds with one stone? Reparative, neuroplastic, cardiorespiratory, and metabolic benefits of aerobic exercise poststroke, Current Opinion in Neurology, 29 (6) (2016) 684-692. [DOI] [PubMed]

[84] E. Molina-Sotomayor, W. Onetti-Onetti, A. Castillo-Rodríguez, J.A. González-Jurado, Changes in Cognitive Function and in the Levels of Glycosylated Haemoglobin (HbA1c) in Older Women with Type 2 Diabetes Mellitus Subjected to a Cardiorespiratory Exercise Programme, Sustainability, 12 (12) (2020) 5038. [DOI]

[85] A. Bielecka-Dabrowa, M.A. Bartłomiejczyk, M. Maciejewski, M. Banach, Post-exercise Hypotension in the Elderly, Hypotensive Syndromes in Geriatric Patients, Springer International Publishing, Cham, (2020) 45-56. [DOI]

[86] D. Umpierre, Physical Activity Advice Only or Structured Exercise Training and Association With HbA ic Levels in Type 2 Diabetes: A Systematic Review and Meta-analysis, Journal of The American Medical Association, 305 (17) (2011) 1790. [DOI] [PubMed]

[87] Y. Mavros, S. Kay, K.A. Simpson, M.K. Baker, Y. Wang, R.R. Zhao, J. Meiklejohn, M. Climstein, A.J. O'Sullivan, N. de Vos, B.T. Baune, S.N. Blair, D. Simar, K. Rooney, N.A. Singh, M.A. Fiatarone Singh, Reductions in Creactive protein in older adults with type 2 diabetes are related to improvements in body composition following a randomized controlled trial of resistance training, Journal of Cachexia and Sarcopenia Muscle, 5 (2) (2014) 111-120. [DOI] [PubMed]

[88] S.M. Abd El-Kader, F.M. Al-Shreef, 
Inflammatory cytokines and immune system modulation by aerobic versus resisted exercise training for elderly, African Health Sciences, 18 (1) (2018) 120-131. [DOI] [PubMed]

[89] H. Cao Dinh, N. Rose, O. Onyema, I. Beyer, K. Liberman, L. De Dobbeleer, W. Renmans, S. Meeren, K. Jochmans, A. Delaere, V. Knoop, I. Bautmans, Strength Endurance Training but Not Intensive Strength Training Reduces Senescence-Prone T Cells in Peripheral Blood in Community-Dwelling Elderly Women, The Journals of Gerontology: Series A, 74 (12) (2018) 1870-1878. [DOI] [PubMed]

[90] C.K. Ryrsø, P. Thaning, C. Siebenmann, C. Lundby, P. Lange, B.K. Pedersen, Y. Hellsten, U.W. Iepsen, Effect of endurance versus resistance training on local muscle and systemic inflammation and oxidative stress in COPD, Scandinavian Journal of Medicine and Science in Sports, 28 (11) (2018) [DOI] [PubMed]

[91] L.N. Forti, E. Van Roie, R. Njemini, W. Coudyzer, I. Beyer, C. Delecluse, I. Bautmans, Load-Specific Inflammation Mediating Effects of Resistance Training in Older Persons, Journal of American Medical Directors Association, 17 (6) (2016) 547-552. [DOI] [PubMed]

[92] K. Liberman, L.N. Forti, I. Beyer, I. Bautmans, The effects of exercise on muscle strength, body composition, physical functioning and the inflammatory profile of older adults: a systematic review, Current Opinion in Clinical Nutrition and Metabolism Care, 20 (1) (2017) 30-53. [DOI] [PubMed]

[93] C. Tomeleri, A. Ribeiro, M. Souza, D. Schiavoni, B. Schoenfeld, D. Venturini, D. Barbosa, K. Landucci, L. Sardinha, E. Cyrino, Resistance training improves inflammatory level, lipid and glycemic profiles in obese older women: A randomized controlled trial, Experimental Gerontology, 84 (2016) 80-87. [DOI] [PubMed]

[94] M.U. Chupel, F. Direito, G.E. Furtado, L.G. Minuzzi, F.M. Pedrosa, J.C. Colado, J.P. Ferreira, E. Filaire, A.M. Teixeira, Strength Training Decreases Inflammation and Increases Cognition and Physical Fitness in Older Women with Cognitive Impairment, Frontiers in Physiology, 8 (337) (2017) 377.
[DOI] [PubMed]

[95] M. Saraiva, A. O'Garra, The regulation of IL-10 production by immune cells, Nature Reviews Immunology, 10 (3) (2010) 170-181. [DOI] [PubMed]

[96] I. Cohen-Manheim, G.M. Doniger, R. Sinnreich, E.S. Simon, R. Pinchas-Mizrachi, J.D. Otvos, J.D. Kark, Increase in the Inflammatory Marker GlycA over 13 Years in Young Adults Is Associated with Poorer Cognitive Function in Midlife, PLOS ONE, 10 (9) (2015) 138036. [DOI] [PubMed]

[97] F. Bobeuf, M. Labonté, A. Khalil, I.J. Dionne, Effect of resistance training on hematological blood markers in older men and women: a pilot study, Current Gerontology Geriatric Research, (2009) 156820. [DOI] [PubMed]

[98] T.-W. Kao, Y.-W. Chang, C.-C. Chou, J. Hu, Y.H. Yu, H.-K. Kuo, White blood cell count and psychomotor cognitive performance in the elderly, European Journal of Clinical Investigation, 41 (5) (2011) 513-520. [DOI] [PubMed]

[99] M.C. Serra, A.S. Ryan, H.K. Ortmeyer, O. Addison, A.P. Goldberg, Resistance training reduces inflammation and fatigue and improves physical function in older breast cancer survivors, Menopause, 25 (2) (2018) 211-216. [DOI] [PubMed]

[100] F.L. Orsatti, E.A. Nahas, N. Maestá, J. Nahas Neto, C. Lera Orsatti, G. Vannucchi Portari, R.C. Burini, Effects of resistance training frequency on body composition and metabolics and inflammatory markers in overweight postmenopausal women, The Journal of Sports Medicine and Physical Fitness, 54 (3) (2014) 317-325. [PubMed]

[101] B.K. McFarlin, M.G. Flynn, W.W. Campbell, L.K. Stewart, K.L. Timmerman, TLR4 is lower in resistance-trained older women and related to inflammatory cytokines, Medicine and Science in Sports and Exercise, 36 (11) (2004) 18761883. [DOI] [PubMed]

[102] M.G. Flynn, B.K. McFarlin, M.D. Phillips, L.K. Stewart, K.L. Timmerman, Toll-like receptor 4 and CD14 mRNA expression are lower in resistive exercise-trained elderly women, Journal of Applied Physiology, 95 (5) (2003) 1833-1842. [DOI] [PubMed] 
[103] K.L. Timmerman, M.G. Flynn, P.M. Coen, M.M. Markofski, B.D. Pence, Exercise traininginduced lowering of inflammatory $(\mathrm{CD} 14+\mathrm{CD} 16+)$ monocytes: a role in the antiinflammatory influence of exercise?, Journal of Leukocyte Biology, 84 (5) (2008) 1271-1278. [DOI] [PubMed]

[104] E.L. Cadore, M. Izquierdo, S.S. Pinto, C.L. Alberton, R.S. Pinto, B.M. Baroni, M.A. Vaz, F.J. Lanferdini, R. Radaelli, M. González-Izal, M. Bottaro, L.F.M. Kruel, Neuromuscular adaptations to concurrent training in the elderly: effects of intrasession exercise sequence, Age (Dordr), 35 (3) (2013) 891903. [DOI] [PubMed]

[105] J.R. Ruiz, X. Sui, F. Lobelo, J.R. Morrow, A.W. Jackson, M. Sjöström, S.N. Blair, Association between muscular strength and mortality in men: prospective cohort study, British Journal of Medicine, 337 (2008) 439. [DOI] [PubMed]

[106] V. Raso, G. Benard, A.J. DA Silva Duarte, V.M. Natale, Effect of resistance training on immunological parameters of healthy elderly women, Medicine Science in Sports \& Exercise, 39 (12) (2007) 2152-2159. [DOI] [PubMed]

[107] J.M. Peake, O. Neubauer, N.P. Walsh, R.J. Simpson, Recovery of the immune system after exercise, Journal of Applied Physiology, 122 (5) (2017) 1077-1087. [DOI] [PubMed]

[108] M.S. Fragala, E.L. Cadore, S. Dorgo, M. Izquierdo, W.J. Kraemer, M.D. Peterson, E.D. Ryan, Resistance Training for Older Adults: Position Statement From the National Strength and Conditioning Association, 33 (8) (2019) 2019-2052. [DOI] [PubMed]

[109] E. Dantas, R. Vale, Protocolo GDLAM de Avaliação da Autonomia Funcional, Fitness \& Performance Journal, 3 (3) (2004), 175-182 (2004). [DOI]

[110] C. Byrne, C. Faure, D.J. Keene, S.E. Lamb, Ageing, muscle power and physical function: a systematic review and implications for pragmatic training interventions, Sports Medicine, 46 (9) (2016) 1311-1332. [DOI] [PubMed]

[111] C. Jaque-Gallardo, P. Véliz-Campillay, J. Cancino-López, Efecto de un entrenamiento con ejercicios de autocarga a alta velocidad en el equilibrio dinámico y estático en mujeres adultas mayores, Revista Médica de Chile, 147
(9) (2019) 1136-1143. [DOI]

[112] P. Doody, J.M. Lord, C.A. Greig, A.C. Whittaker, Assessing the feasibility and impact of specially adapted exercise interventions, aimed at improving the multi-dimensional health and functional capacity of frail geriatric hospital inpatients: protocol for a feasibility study, British Journal of Medicine Open, 9 (11) (2019) e031159. [DOI] [PubMed]

[113] M.J. Gibala, J.P. Little, M.J. Macdonald, J.A. Hawley, Physiological adaptations to lowvolume, high-intensity interval training in health and disease, Journal of Physiology, (London). 590 (5) (2012) 1077-1084. [DOI] [PubMed]

[114] A.E. Tjønna, S.J. Lee, Ø. Rognmo, T.O. Stølen, A. Bye, P.M. Haram, J.P. Loennechen, Q.Y. AlShare, E. Skogvoll, S.A. Slørdahl, O.J. Kemi, S.M. Najjar, U. Wisløff, Aerobic interval training versus continuous moderate exercise as a treatment for the metabolic syndrome: a pilot study, Circulation, 118 (4) (2008) 346-354. [DOI] [PubMed]

[115] K. Karstoft, C.S. Christensen, B.K. Pedersen, T.P.J. Solomon, The acute effects of intervalVs continuous-walking exercise on glycemic control in subjects with type 2 diabetes: a crossover, controlled study, Journal of Clinical and Endocrinology Metabolism, 99 (9) (2014) 3334-3342. [DOI] [PubMed]

[116] J.B. Gillen, J.P. Little, Z. Punthakee, M.A. Tarnopolsky, M.C. Riddell, M.J. Gibala, Acute high-intensity interval exercise reduces the postprandial glucose response and prevalence of hyperglycaemia in patients with type 2 diabetes, Diabetes, Obesity and Metabolism, 14 (6) (2012) 575-577. [DOI] [PubMed]

[117] $\varnothing$. Rognmo, T. Moholdt, H. Bakken, T. Hole, P. Mølstad, N.E. Myhr, J. Grimsmo, U. Wisløff, Cardiovascular risk of high-versus moderateintensity aerobic exercise in coronary heart disease patients, Circulation, 126 (12) (2012) 1436-1440. [DOI] [PubMed]

[118] K.S. Beetham, E.J. Howden, R.G. Fassett, A. Petersen, A.J. Trewin, N.M. Isbel, J.S. Coombes, High-intensity interval training in chronic kidney disease: A randomized pilot study, Scandinavian Journal of Medicine and Science in Sports, 29 (8) (2019) 1197-1204. [DOI] [PubMed] 
[119] C.-L. Hwang, J. Lim, J.-K. Yoo, H.-K. Kim, M.H. Hwang, E.M. Handberg, J.W. Petersen, B.J. Holmer, J.A. Leey Casella, K. Cusi, D.D. Christou, Effect of all-extremity high-intensity interval training vs. moderate-intensity continuous training on aerobic fitness in middle-aged and older adults with type 2 diabetes: A randomized controlled trial, Experimental Gerontology, 116 (2019) 46-53. [DOI] [PubMed]

[120] J. Losa-Reyna, I. Baltasar-Fernandez, J. Alcazar, R. Navarro-Cruz, F.J. Garcia-Garcia, L.M. Alegre, A. Alfaro-Acha, Effect of a short multicomponent exercise intervention focused on muscle power in frail and pre frail elderly: A pilot trial, Experimental Gerontology, 115 (2019) 114-121. [DOI] [PubMed]

[121] J.P. Little, M.E. Francois, High-intensity interval training for improving postprandial hyperglycemia, Research Quarterly for Exercise and Sport, 85 (4) (2014) 451-456. [DOI] [PubMed]

[122] J.P. Little, J.B. Gillen, M.E. Percival, A. Safdar, M.A. Tarnopolsky, Z. Punthakee, M.E. Jung, M.J. Gibala, Low-volume high-intensity interval training reduces hyperglycemia and increases muscle mitochondrial capacity in patients with type 2 diabetes, Journal of Applied Physiology,111 (6) (2011) 1554-1560. [DOI] [PubMed]

[123] Ø. Rognmo, E. Hetland, J. Helgerud, J. Hoff, S.A. Slørdahl, High intensity aerobic interval exercise is superior to moderate intensity exercise for increasing aerobic capacity in patients with coronary artery disease, European Journal of Cardiovascular Prevention \& Rehabilitation, 11 (3) (2004) 216-222. [DOI] [PubMed]

[124] J. Myers, M. Prakash, V. Froelicher, D. Do, S. Partington, J.E. Atwood, Exercise capacity and mortality among men referred for exercise testing, New England Journal of Medicine, 346 (11) (2002) 793-801. [DOI] [PubMed]

[125] C. Coetsee, E. Terblanche, The effect of three different exercise training modalities on cognitive and physical function in a healthy older population, European Review of Aging Physical Activity, 14 (2017). [DOI] [PubMed]

[126] C. Durrer, M. Francois, H. Neudorf, J.P. Little, Acute high-intensity interval exercise reduces human monocyte Toll-like receptor 2 expression in type 2 diabetes, American Journal of Physiology-Regulatory, Integrative and Comparative Physiology, 312 (4) (2017) R529-R538. [DOI] [PubMed]

[127] G.P. Fadini, S.V. de Kreutzenberg, E. Boscaro, M. Albiero, R. Cappellari, N. Kränkel, U. Landmesser, A. Toniolo, C. Bolego, A. Cignarella, F. Seeger, S. Dimmeler, A. Zeiher, C. Agostini, A. Avogaro, An unbalanced monocyte polarisation in peripheral blood and bone marrow of patients with type 2 diabetes has an impact on microangiopathy, Diabetologia, 56 (8) (2013) 1856-1866. [DOI] [PubMed]

[128] M.R. Dasu, Ramirez S, Isseroff RR, Toll-like receptors and diabetes: a therapeutic perspective, Clinical Science, 122 (5) (2012) 203-14. [DOI] [PubMed]

[129] S. Khan, A.A. Chuturgoon, D.P. Naidoo, Telomeres and atherosclerosis, Cardiovascular Journal of Africa, 23 (10) (2021) 563-71. [DOI] [PubMed]

[130] T. You, N.C. Arsenis, B.L. Disanzo, M.J. Lamonte, Effects of exercise training on chronic inflammation in obesity: current evidence and potential mechanisms, Sports $\begin{array}{lll}\text { Medicine, 43(4) (2013) 243-56. [DOI] } & \end{array}$ [PubMed]

[131] David B Bartlett, Leslie H Willis, Cris A Slentz, Andrew Hoselton, Leslie Kelly, Janet L Huebner, Virginia B Kraus, Jennifer Moss, Michael J Muehlbauer, Guillaume Spielmann, William E Kraus 4, Janet M Lord, Kim M Huffman, Ten weeks of high-intensity interval walk training is associated with reduced disease activity and improved innate immune function in older adults with rheumatoid arthritis: a pilot study. Arthritis Research Therapy, 20(1) (2018) 127. [DOI] [PubMed]

A. Saxena, D. Minton, D. Lee, X. Sui, R. Fayad, C.J. Lavie, S. Blair, Protective role of resting heart rate on all-cause and cardiovascular disease mortality. Mayo Clinic Proceedings, 88 (12) (2013) 1420-6. [DOI] [PubMed]

[133] N. R. Poulter, D. Prabhakaran, M. Caulfield, Hypertension, Lancet, 386 (9995) (2015) 80112. [DOI] [PubMed]

[134] J. Cedergren, T. Forslund, T. Sundqvist, T. Skogh. Intracellular oxidative activation in synovial fluid neutrophils from patients with rheumatoid arthritis but not from other arthritis patients, Journal of Rheumatology, 34(11) (2007) 2162-70. [PubMed]

[135] M. Tsukamoto, N. Seta, K. Yoshimoto, K. 
Suzuki, K. Yamaoka, T. Takeuchi, CD14bright $\mathrm{CD} 16+$ intermediate monocytes are induced by interleukin-10 and positively correlate with disease activity in rheumatoid arthritis, Arthritis Research \& Therapy, 19(1) (2017) 28. [DOI] [PubMed]

[136] Flávia Mariel Steckling, Juliano Boufleur Farinha, Felipe da Cunha Figueiredo, Daniela Lopes Dos Santos, Guilherme Bresciani, Nélson Alexandre Kretzmann, Sílvio Terra Stefanello, Aline Alves Courtes, Maristela de Oliveira Beck, Manuela Sangoi Cardoso, Marta Maria Medeiros Frescura Duarte, Rafael Noal Moresco, Félix Alexandre Antunes Soares, High-intensity interval training improves inflammatory and adipokine profiles in postmenopausal women with metabolic syndrome, Archives of Physiology and Biochemistry, 125 (2019) 85-91. [DOI] [PubMed]

[137] P. Soysal, F. Arik, L. Smith, S.E. Jackson, A.T. Isik,Inflammation, Frailty and Cardiovascular

Disease, Advances in Experimental Medicine and Biology, 1216 (2020) 55-64. [DOI] [PubMed]

[138] R. Shibata, N. Ouchi, T. Murohara, Adiponectin and cardiovascular disease, Circulation Journal, 73 (4) (2009) 608-614. [DOI] [PubMed]

[139] I. Falcão-Pires, P. Castro-Chaves, D. MirandaSilva, A.P. Lourenço, A.F. Leite-Moreira, Physiological, pathological and potential therapeutic roles of adipokines, Drug Discovery Today, 17 (15-16) (2012) 880-889. [DOI] [PubMed]

[140] J. Heggelund, K.D. Kleppe, G. Morken, E. Vedul-KjelsÃ $¥ s$, High Aerobic Intensity Training and Psychological States in Patients with Depression or Schizophrenia, Frontiers in Psychiatry, 5 (2014). [DOI] [PubMed]

[141] D. Watson, L.A. Clark, A. Tellegen, Development and validation of brief measures of positive and negative affect: the PANAS scales, Journal of Personality and Social Psychology, 54 (6) 1063-1070. [DOI] [PubMed]

[142] J.P. Little, M.E. Francois, High-intensity interval training for improving postprandial hyperglycemia, Research Quarterly for Exercise and Sport, 85 (4) (2014) 451-456. [DOI] [PubMed]

[143] L.S. Pescatello, B.A. Franklin, R. Fagard, W.B. Farquhar, G.A. Kelley, C.A. Ray, T. pronouncement was written for the American College of Sports Medicine by, Exercise and Hypertension, Medicine \& Science in Sports \& Exercise, 36 (3) (2004) 533-553. [DOI]

[144] ACSM, Exercise and Type 2 Diabetes: American College of Sports Medicine and the American Diabetes Association Joint Position Statement, Medicine \& Science in Sports \& Exercise, 42 (12) (2010) 2282-2303. [DOI]

[145] American College of Sports Medicine position stand. Exercise for Patients with Coronary Artery Disease, Medicine \& Science in Sports \& Exercise, 26 (3) (1994) i-v. [PubMed]

\section{Acknowledgement}

Coordenação de Aperfeiçoamento de Pessoal de Nível Superior (CAPES), Conselho Nacional de Desenvolvimento Científico e Tecnológico (CNPq), Fundação de Amparo à Pesquisa do Estado de Minas Gerais (FAPEMIG).

\section{Funding}

Samuel Gonçalves Almeida da Encarnação received a Master's scholarship from CAPES. Sthéfany Lemos Fazolo received a graduate scholarship from CNPq.

\section{Does this article screened for similarity? Yes.}

\section{Author Contribution}

Samuel Gonçalves Almeida da Encarnação - Study design, methodology and wrote the paper; Osvaldo Costa Moreira - Academic guidance, manuscript editing and review; Sthéfany Lemos Fazolo Methodology and wrote the paper; Cláudia Eliza Patrocínio de Oliveira - Academic guidance, manuscript editing and review; Irismar Gonçalves Almeida da Encarnação - Methodology and wrote the paper; Miguel Araújo Carneiro-Júnior Supervision and academic guidance, study design, methodology, wrote the paper, manuscript editing and review. All the authors read and approved the final version of the manuscript.

\section{Conflict of interest}

The Authors have no conflicts of interest to declare that they are relevant to the content of this article.

\section{About The License}

(C) The Author(s) 2021. The text of this article is open access and licensed under a Creative Commons Attribution 4.0 International License 